\title{
Multiphase response of palynomorphs to the Toarcian Oceanic Anoxic Event (Early Jurassic) in the Réka Valley section, Hungary
}

\author{
Viktória Baranyi ${ }^{\mathrm{a}, *}$, József Pálfy b,c , Ágnes Görög a , James B. Riding ${ }^{\mathrm{d}}$, Béla Raucsik ${ }^{\mathrm{e}}$ \\ a Department of Palaeontology, Eötvös Loránd University, Pázmány Péter sétány 1/C, Budapest H-1117, Hungary \\ b Department of Physical and Applied Geology, Eötvös Loránd University, Pázmány Péter sétány 1/C, Budapest H-1117, Hungary \\ c MTA-MTM-ELTE Research Group for Paleontology, POB 137, Budapest H-1431, Hungary \\ d British Geological Survey, Environmental Science Centre, Keyworth, Nottingham NG12 5GG, United Kingdom \\ e Department of Mineralogy, Geochemistry and Petrology, University of Szeged, Egyetem utca 2, Szeged H-6722, Hungary
}

\section{A R T I C L E I N F O}

\section{Article history:}

Received 2 September 2015

Received in revised form 13 September 2016

Accepted 24 September 2016

Available online 30 September 2016

\section{Keywords:}

Dinoflagellate cysts

Early Jurassic

Mecsek Mountains

Hungary

Palynofacies

Prasinophytes

Toarcian Oceanic Anoxic Event (T-OAE)

\begin{abstract}
A B S T R A C T
Major palaeoenvironmental and palaeoceanographical changes occurred during the Early Jurassic Toarcian Oceanic Anoxic Event (T-OAE), due to a perturbation of the global carbon cycle and a crisis in marine ecosystems. The sequence of environmental change and regional differences during the T-OAE are not yet fully understood and organic-walled phytoplankton and other palynomorphs are well-suited, but under-utilised, in research into this event. Based on quantitative palynological analyses from a black shale-bearing succession at Réka Valley in the Mecsek Mountains of southwest Hungary, five sequential palynomorph assemblages are distinguished. These reveal major shifts in organic-walled phytoplankton communities, driven by palaeoenvironmental changes. In addition, palynofacies analysis helped to document changes in the composition of sedimentary organic matter, and to quantify the terrestrial input. Assemblage 1 is characterised by a moderately diverse phytoplankton community and high levels of terrestrial palynomorphs. Assemblage 2 records a significant peak of the euryhaline dinoflagellate cyst Nannoceratopsis. Assemblage 3 is distinguished by dominance of highly opportunistic prasinophytes and the temporary disappearance of all dinoflagellate cyst taxa. Assemblages 4 and 5 represent distinctive phases of a prolonged recovery phase with low diversity phytoplankton assemblages and intermittently high levels of terrestrially-derived palynomorphs. The successive disappearance of phytoplankton taxa and the gradual takeover by opportunistic euryhaline species at the onset of the T-OAE were related to several phenomena. These include reduced salinity in the surface waters, establishment of a stable pycnocline and deterioration of nutrient recycling, followed by oxygen deficiency throughout much of the water column. The high amount of terrestrially-derived palynodebris indicates intense runoff and freshwater input, driven by the early Toarcian warming and the enhanced hydrological cycle. Comparison with coeval European successions proves that the palaeoenvironmental changes during the T-OAE were not entirely synchronous, and local factors played a crucial role in influencing phytoplankton communities. In the Mecsek Basin, regional freshening of the surface waters and increased terrestrial input due to the proximity of the hinterland had a greater influence on phytoplankton communities compared to the open oceanic setting of the Tethys to the south.
\end{abstract}

(c) 2016 Elsevier B.V. All rights reserved.

\section{Introduction}

The early Toarcian (Early Jurassic, $\sim 183-179 \mathrm{Ma}$ ) was a time of severe palaeoenvironmental perturbations. Global warming, sea level rise and the associated geochemical changes in the ocean-atmosphere system led to a multiplicity of palaeoenvironmental changes which significantly stressed the biosphere and caused biotic turnovers. Marine transgression, carbon isotope excursions, other geochemical anomalies and widespread deposition of organic-rich sediments are associated with the Toarcian Oceanic Anoxic Event (T-OAE) (Jenkyns, 1988;

\footnotetext{
* Corresponding author at: Department of Geosciences, University of Oslo, POB 1047 Blindern, 0316 Oslo, Norway.

E-mail address: viktoria.baranyi@geo.uio.no (V. Baranyi).
}

McArthur et al., 2000; Schouten et al., 2000; Jenkyns et al., 2002; Bailey et al., 2003; Van de Schootbrugge et al., 2005a; Hesselbo et al., 2007; Suan et al., 2008; Littler et al., 2009; Korte and Hesselbo, 2011; Hermoso et al., 2013). A plausible initial triggering mechanism for the palaeoenvironmental perturbations is methane hydrate dissociation (Hesselbo et al., 2000, 2007). However the most likely, and less debated, main cause of these paleoenvironmental changes was the emplacement of the Karoo-Ferrar large igneous province (Pálfy and Smith, 2000; McElwain et al., 2005; Svensen et al., 2007; Suan et al., 2008; Burgess et al., 2015).

The T-OAE is associated with a minor mass extinction in several taxonomic groups (e.g. Harries and Little, 1999; Pálfy and Smith, 2000; Wignall, 2001; Caruthers et al., 2013; Caswell and Coe, 2013; Danise et al., 2013). Coeval environmental perturbations include increased 
terrestrial input due to enhanced weathering and riverine influx, stratification of the water column with subsequent anoxia and ocean acidification. These changes caused severe stress for many phytoplankton groups. The effects of oceanic anoxic events on phytoplankton assemblages have been discussed extensively (Bucefalo Palliani et al., 1998, 2002; Bucefalo Palliani and Riding, 1999a; Erba, 2004; Mattioli et al., 2004, 2009; Van de Schootbrugge et al., 2005b, 2013). Dinoflagellate cysts are one of the major groups of Early Jurassic fossilisable phytoplankton. The dinoflagellates are a diverse eukaryotic protistan group of extant unicellular phytoplankton, and are important primary producers at the base of the marine and freshwater food chains (Taylor et al., 2008). Many dinoflagellates have at least two distinct stages in their life cycle. During the motile stage, they inhabit the photic zone and their distribution is affected mostly by surface water temperature, salinity, nutrient availability and light penetration (Marret and Zonneveld, 2003). Many dinoflagellates include a fossilisable resting cyst in their life cycle; these hypnozygotic cysts are extremely useful in studies of Mesozoic and Cenozoic biostratigraphy, palaeobiology and palaeoecology (Stover et al., 1996). Cyst-producing dinoflagellates are very sensitive to ecological conditions, especially oxygen availability
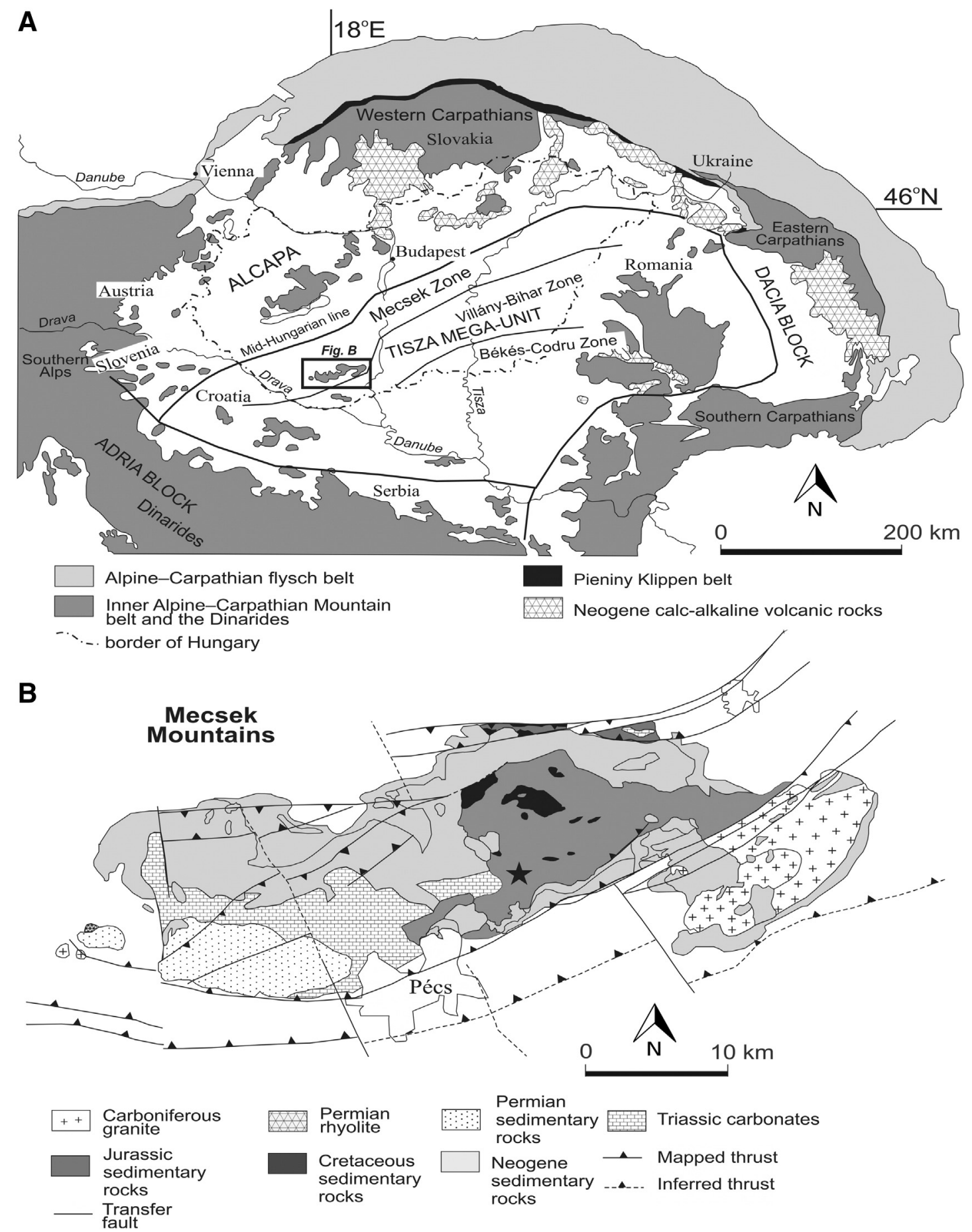

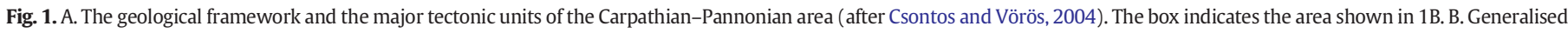

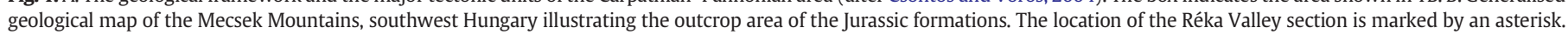
Modified after Raucsik and Varga (2008a), with structural geology from Csontos et al. (2002). 
in the bottom waters due to the benthic habitat of the resting cysts (Wall et al., 1977; Anderson et al., 1987). Therefore, due to the planktonic and benthic stages in their life cycle, dinoflagellate cysts provide information on the ecological conditions and physico-chemical properties of both the surface and bottom waters.

Many studies on Early Jurassic dinoflagellate cyst assemblages have focused on their biostratigraphy, palaeobiogeography and taxonomy, (e.g. Gocht, 1964; Davies, 1985; Prauss, 1989; Feist-Burkhardt and Wille, 1992; Riding and Thomas, 1992; Bucefalo Palliani and Riding, 2003a). Palynological aspects of the T-OAE have been discussed by Loh et al. (1986), Prauss (1996), Bucefalo Palliani et al. (1998, 2002), Bucefalo Palliani and Riding (1999a) and van de Schootbrugge et al. (2005b, 2013). These studies aimed to reconstruct the palaeoenvironmental changes associated to the T-OAE using calcareous nannoplankton, dinoflagellate cysts and other organic-walled microplankton groups. The environmental stress that accompanied the TOAE led to a turnover of dinoflagellate cysts (Bucefalo Palliani and Riding, 1999b; Bucefalo Palliani et al., 2002). The genera Luehndea and Umbriadinium, together with many species either became extinct or temporarily disappeared (Bucefalo Palliani and Riding, 2003a, 2003b).

The objective of this study is to analyse the changes in organicwalled phytoplankton groups (i.e. dinoflagellate cysts and prasinophytes), together with changes in the input of terrestrially-derived material, in a black shale-bearing sequence in the Mecsek Mountains of southwest Hungary. Our principal aim is to reconstruct the pattern of biotal turnover associated with the T-OAE. Comparing microplankton turnover patterns from other localities from the Boreal Realm (e.g. Germany, UK) and the Tethyan Realm (e.g. central Italy), we attempt to elucidate regional and global trends in organic-walled phytoplankton community change and to assess the overprint of regional palaeogeographical effects on global phenomena. In addition, building on previous studies such as Dybkjær (1991), Tyson (1993, 1995), Feist-Burkhardt et al. (2008) and Götz et al. (2008), we record and interpret changes in palynofacies patterns during the T-OAE.

\section{Geological setting}

The Mecsek Mountains are situated in the southwestern part of the Pannonian Basin in Hungary (Fig. 1A). They form the only exposed part of the Mecsek Zone structural unit that belongs to the Tisza Mega-unit (Fig. 1B; Csontos and Vörös, 2004; Haas and Péró, 2004). The Tisza Mega-unit consists of tectonic blocks of the European Plate that were accreted during the Variscan orogeny, and broke off the southern margin of the European Platform (Fig. 2). It reached its present position after a series of drifting and rotation events during the Paleogene and Neogene (Csontos et al., 1992, 2002).

During the Triassic and Early Jurassic, the Mecsek Basin was located east of the Bohemian Massif, and was an epicontinental depocentre (Fig. 2; Haas and Péró, 2004). The Mecsek Basin was situated close to the continental margin, and was therefore exposed to significant terrigeneous influence (Bleahu et al., 1994). The Upper Triassic to lowermost Jurassic succession is characterised by fluvial, lacustrine, coal-

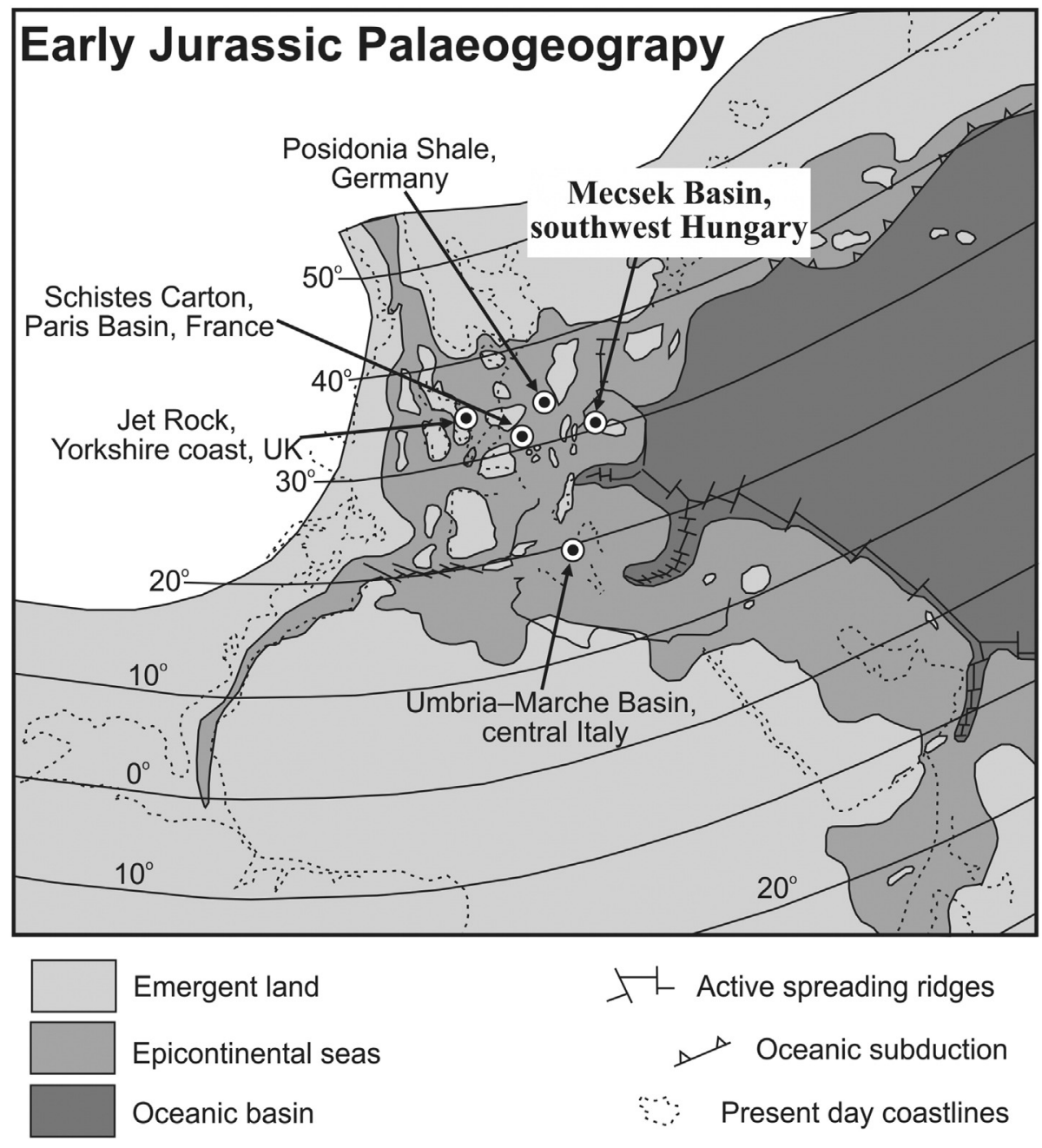

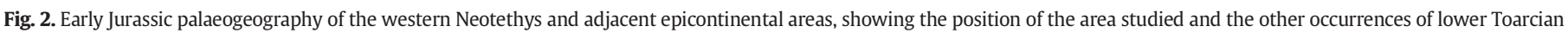
black shale discussed in the text (Jenkyns, 1988). Modified after Varga et al. (2007); base map after Bassoulet et al. (1993). 

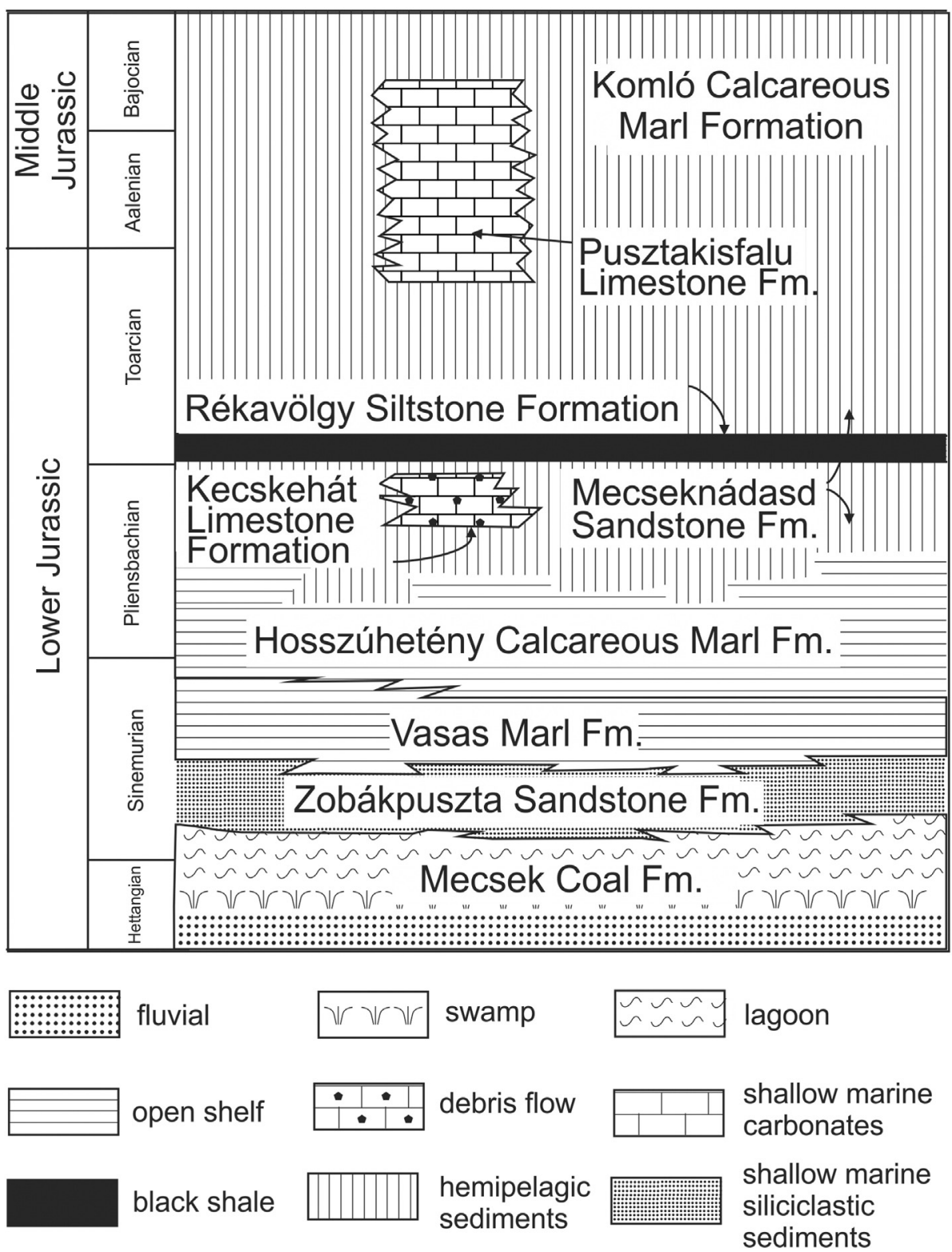

Fm. Formation

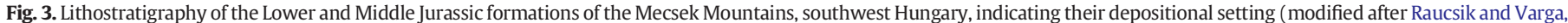
2008a).

bearing swamp and deltaic deposits of the Mecsek Coal Formation (Fig. 3; Szente, 2012). The early Sinemurian eustatic sea level rise coincided with rapid subsidence of the Mecsek Basin, and led to a decrease of terrigenous input and deepening of the depositional environment, as reflected by the Vasas Marl Formation (Fig. 3; Császár et al., 2007; Raucsik, 2012a). During the late Sinemurian and Pliensbachian, terrigeneous material mixed with biogenic carbonate was deposited in this open marine, relatively deep basin and formed an intensely bioturbated lithofacies, assigned to the Hosszúhetény Calcareous Marl Formation (Fig. 3). This unit is informally known as spotted marl, and it is the equivalent of Fleckenmergel or Allgäu facies elsewhere in the European margin of the Neotethys (Adámek, 2005; Horváth and Galácz, 2006; Raucsik, 2012b). Interbedded bituminous limestones, crinoidal limestones and turbiditic sandstones occur within the monotonous Upper Pliensbachian hemipelagic spotted marl succession, suggesting variable controls on climate change, sea level fluctuations and tectonism (Raucsik and Varga, 2008a). The organic-rich silty and clayey marls of the lower Toarcian Rékavölgy Siltstone Formation mark the establishment of suboxic/anoxic conditions in the Mecsek Basin (Fig. 3; Raucsik, 2012c). The T-OAE is represented by an $\sim 12$ m thick black shale succession (Dulai et al., 1992; Raucsik, 2008, 2012c). Overlying the black shales, sedimentation of the spotted marl resumed and continued through to the latest Bajocian Komló Calcareous Marl Formation (Fig. 3; Raucsik, 2012d). Marked sedimentological changes took place in the Mecsek Basin during the Middle Jurassic. The amount of terrigeneous input dramatically decreased. This, together with accelerated subsidence, led to the formation of a deep pelagic basin marking the separation of the Tisza Mega-unit from the European Plate due to the opening of the Penninic oceanic branch (Horváth and Galácz, 2006).

\section{The stratigraphy of the Réka Valley section}

Jurassic strata are exposed in the eastern part of the Mecsek syncline (Fig. 1A,B; Némedi Varga, 1998). The section studied is located near the NE-SW trending Réka Valley, south of Óbánya (Fig. 4). The 12 m thick black shale succession crops out in a small tributary ravine. The section 


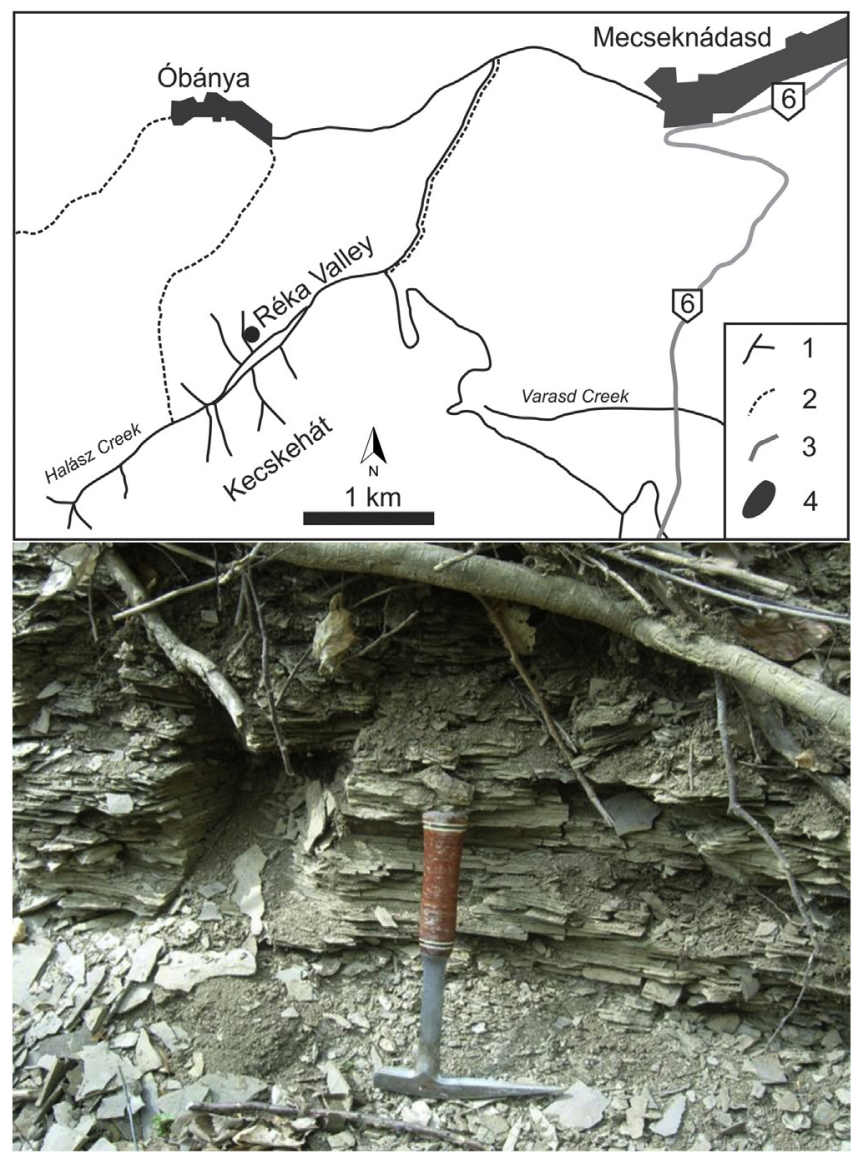

Fig. 4. Location map of the section investigated (above), and a close-up photograph of the outcrop (below). Key: 1 - creek; 2 - trail; 3 - road; 4 - settlement. Modified after Raucsik and Varga (2008b).

was described in detail by Galácz (1991), Dulai et al. (1992) and Raucsik and Varga (2008a, 2008b). The lower part of the section exposes a rhythmic succession of intensely bioturbated calcareous and clayey marl beds (spotted marl) with intercalations of mixed carbonatesiliciclastic lenses (Fig. 5). The spotted marl succession is interrupted by a black shale unit which consists of light brown to dark grey bituminous shale and greyish clayey marl layers with distinct lamination at some levels, with bivalves, fish, plant fragments, and common pyrite framboids and moulds (Dulai et al., 1992; Raucsik, 2008). Intercalations of calcareous-siliciclastic turbidite beds occur in the upper part of the black shale unit, above which is more spotted marl facies (Fig. 5).

The ammonites Hildaites cf. gyralis, $H$. cf. levisoni and $H$. cf. siemensi in the black shales, together with Harpoceras cf. exaratum from directly above the uppermost black shale beds, indicate the lower Toarcian Harpoceras falciferum ammonite biozone (Galácz, 1991). However, due to the somewhat sporadic occurrence of ammonites, the base of the Toarcian, and the boundary between the Dactilyoceras tenuicostatum and $H$. falciferum ammonite biozones remain poorly constrained (Galácz, 1991; Dulai et al., 1992; Baldanza et al., 1995; Varga et al., 2009). Based on calcareous nannoplankton, Baldanza et al. (1995) suggested that the boundary between the $D$. tenuicostatum and $H$. falciferum ammonite biozones may lie several metres above the base of the black shale (Fig. 5). In sample BS 15 ( $1 \mathrm{~m}$ below sample BS 16), Mattioli in Varga et al. (2009) encountered the calcareous nannoplankton species Carinolithus poulnabronei, which often occurs together with C. superbus in early Toarcian assemblages, and indicates the D. tenuicostatum ammonite biozone. Sample BS 59 (1 m above sample BS 58) yielded Watznaueria colacicchii and $W$. fossacincta. The first appearances of these species are normally coincident with the inception of Discorhabdus striatus, indicating correlation with the uppermost part of the H. falciferum ammonite biozone (Mattioli and Erba, 1999). The dinoflagellate cyst assemblages of the Réka Valley section were studied by Baldanza et al. (1995) and Bucefalo Palliani et al. (1997), who focussed on biostratigraphy, palaeogeography and taxonomy. The species Luehndea cirilliae and L. microreticulata were first described from the Réka Valley section by Bucefalo Palliani et al. (1997).

The total organic carbon (TOC) values of the strata studied vary from 3.89 to $8.12 \%$ in the black shales, and 2.14 to $3.29 \%$ in the marls (Varga et al., 2007). Investigation of samples from the lower $5 \mathrm{~m}$ of the black shale succession show that the organic macerals are virtually all liptinite, and are mainly marine-derived (Varga et al., 2007). The carbon isotopic composition of the kerogen ranges from $-30.9 \%$ o to $-28.6 \%$ relative to V-PDB (Varga et al., 2007). These values are slightly less negative than in other Toarcian organic-rich formations, yet strongly suggest a correlation with the characteristic carbon isotope excursion of the TOAE (Jenkyns et al., 2002). The carbon and oxygen isotopic composition of the carbonate fraction has been altered diagenetically, therefore they cannot be used in palaeoenvironmental interpretations (Varga et al., 2007). The clay minerals in the black shales are dominated by kaolinite (Raucsik and Varga, 2008a, 2008b), which is typical of strongly leached soils that have become progressively enriched in aluminium (Van de Schootbrugge et al., 2009). This indicates extremely high continental weathering rates in the source area related to humid, tropical-subtropical climatic conditions (Branski, 2010).

\section{Material and methods}

Thirty-five samples, BS 2-58, from the Réka Valley section were analysed herein (Fig. 5). Palynomorphs from this black shale succession were extracted from these horizons, which is the same sample set as in Varga et al. (2007) and Raucsik and Varga (2008a, 2008b). Additional palynology samples were collected from the strata underlying and overlying the black shale; these were numbered RV 1-20.

All the samples were prepared using the standard palynological processing techniques of Wood et al. (1996), including treatment with concentrated $\mathrm{HCl}$ and $\mathrm{HF}$ for the dissolution of carbonate and silicate minerals respectively. For density separation, $\mathrm{ZnCl}_{2}$ solution (density $2.2 \mathrm{~g} / \mathrm{cm}^{3}$ ) was used. To reduce amorphous organic matter (AOM), black shale samples were oxidised using either $\mathrm{NaOH}$, a mixture of $\mathrm{NaOH}$ and $\mathrm{HNO}_{3}$, or Schulze's solution (a mixture of an aqueous solution of $\mathrm{KClO}_{3}$ and concentrated $\left.\mathrm{HNO}_{3}\right)$. To avoid the loss of small $(\sim 20 \mu \mathrm{m})$ palynomorphs, the organic residues were not sieved. Microscope slides were mounted using glycerine jelly.

The relative percentage of palynomorphs is based on counts of $\sim 200$ grains and using up to four microscope slides. Sample RV 5 proved barren, and samples BS 48, BS 46, BS 44, RV 17, RV 19 and RV 20 were palynologically sparse; i.e. $<30$ specimens were recovered. Dinoflagellate cysts were relatively low in diversity and moderately well preserved. By contrast, the terrestrially-derived palynomorphs were highly diverse and generally well preserved with a colouration index of 1 to 2 using the thermal alteration scale of Batten (2002). The relative abundance of palynomorphs was calculated and plotted using Tilia/TiliaGraph software (Grimm, 1991-2001). The palynomorph assemblages were defined using constrained cluster analysis using CONISS (Grimm, 1987) within Tilia (Fig. 6).

Palynofacies analysis was undertaken to determine the type and preservation of the sedimentary organic matter, and the amount of terrigenous input. The subdivision and terminology of the kerogen types follows Oboh-Ikuenobe and de Villiers (2003) (see Table 1). Four palynofacies parameters were calculated on the basis of counting $\sim 400$ organic grains per slide. These were: the ratio of terrestrial to marine palynomorphs $(\mathrm{t} / \mathrm{m})$; the ratio of spores to bisccate pollen grains ( $\mathrm{sp} / \mathrm{bs})$; the ratio of opaque to translucent phytoclasts (op/tr); and the ratio of bladder or lath-shaped to equidimensional opaque phytoclasts (bl/eq). This methodology follows Tyson (1993), Pittet and Gorin 

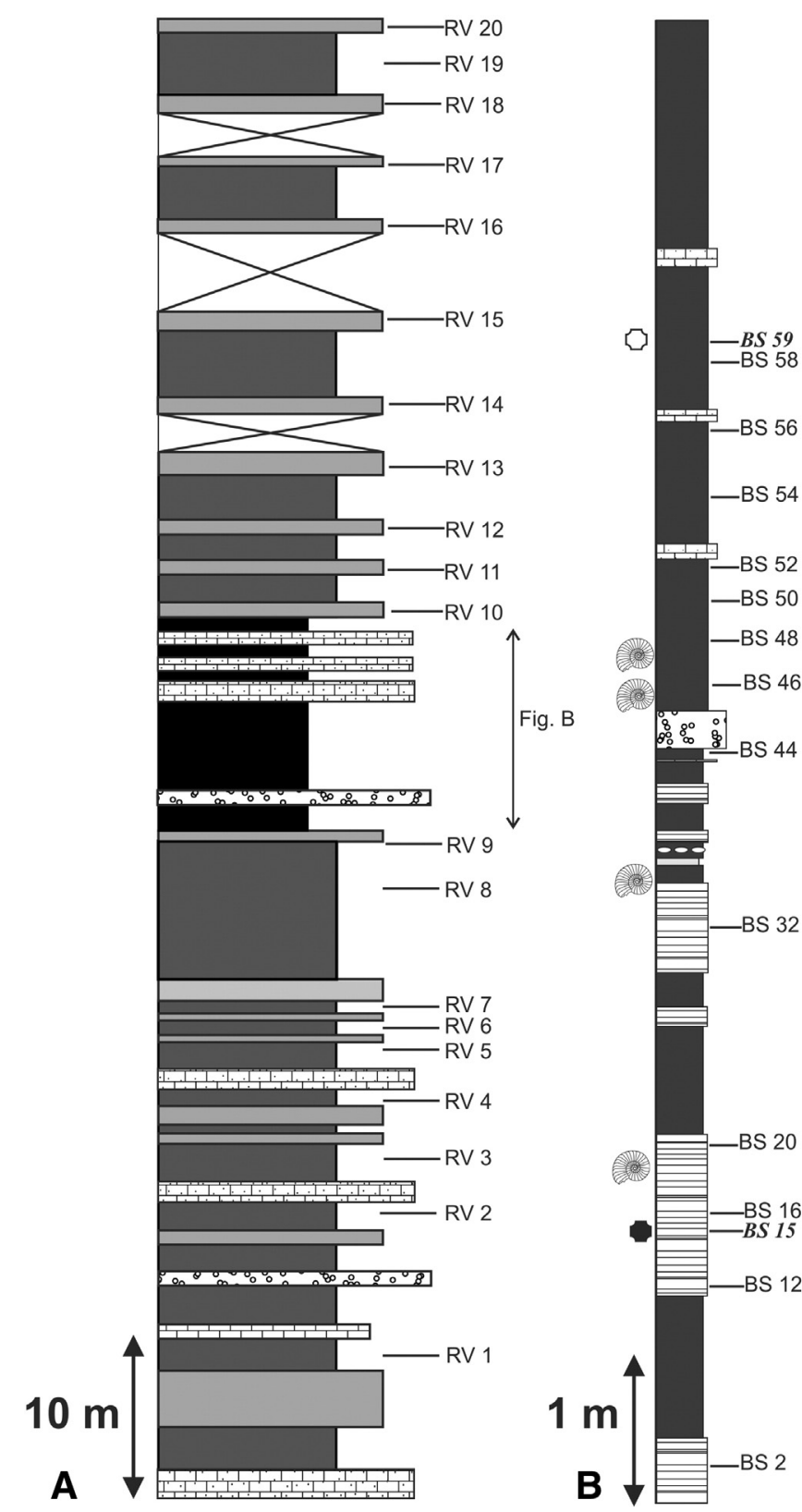

\begin{tabular}{|c|c|}
\hline 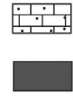 & $\begin{array}{l}\text { redeposited crinoidal } \\
\text { limestone } \\
\text { clayey marl }\end{array}$ \\
\hline & calcareous marl \\
\hline & black shale \\
\hline & limestone \\
\hline & sandstone \\
\hline & unexposed \\
\hline & grey clay \\
\hline & laminated black shale \\
\hline 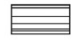 & thin layered black shale \\
\hline & $\mathrm{ncr}$ \\
\hline
\end{tabular}

ammonites indicating Harpoceras falciferum ammonite Zone occurrence of the calcareous nannofossil Carinolithus poulnabronei in BS 15 occurrence of the calcareous nannofossil Watznaueria fossacincta and $W$. colacicchii in BS 59

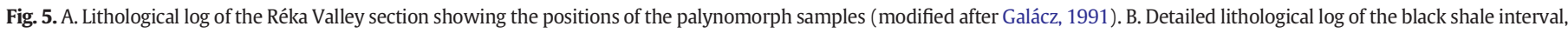
modified after Raucsik and Varga (2008b) and Varga et al. (2009).

(1997), Feist-Burkhardt et al. (2008) and Götz et al. (2008) (Fig. 7, Table 1).

Despite multiple oxidation treatments, the black shale samples yielded large amounts of AOM that made the identification of palynomorphs and phytoclasts difficult or impossible. The AOM was analysed under fluorescent light to evaluate the preservational state of the sedimentary organic matter, and to distinguish the palynomorphs and phytoclasts that are masked by the AOM in light microscopy. However, fluorescence microscopy proved unsuitable because of the intense autofluorescence of the glycerine jelly. Furthermore, the intense fluorescent light damages this mounting material. For these reasons, meaningful palynofacies analyses could only be carried out in the underlying and overlying units. Results from the black shale samples are not reliable, and are not used for comparison to the other samples.

Optical microscopy was carried out in the Department of Palaeontology, Eötvös Loránd University, Budapest, Hungary using a Nikon Eclipse E600 microscope. The fluorescence microscopy was undertaken at the Department of Botany, Hungarian Natural History
Museum, using a Nikon Eclipse E600 equipped with a fluorescent light source. All samples, residues and microscope slides, including the figured specimens (Plates I-III), are curated at the Department of Palaeontology, Eötvös Loránd University. Palynomorph and palynofacies counts are available as online supplementary material. The nannoplankton samples of E. Mattioli are curated at the Collections de Géologie de Lyon with FSL numbers from 765,965 to 765,996.

Data analysis and calculation of the diversity indices were carried out using the PAST software package 3.01 (Hammer et al., 2001). Samples containing $<30$ specimens were excluded from the data analyses. For each sample, the diversity of the marine phytoplankton was expressed using the Simpson Diversity Index (1-D). This is a suitable method because the palynomorph abundances are heterogenous. The Simpson Diversity Index takes into account the number of taxa. It ranges between 0 for monospecific assemblages and 1 where all taxa are equally abundant. The index assesses the probability that two individuals randomly selected from a sample will belong to a different taxon, and the greater the 1-D value, the greater the diversity (e.g. Danise et al., 


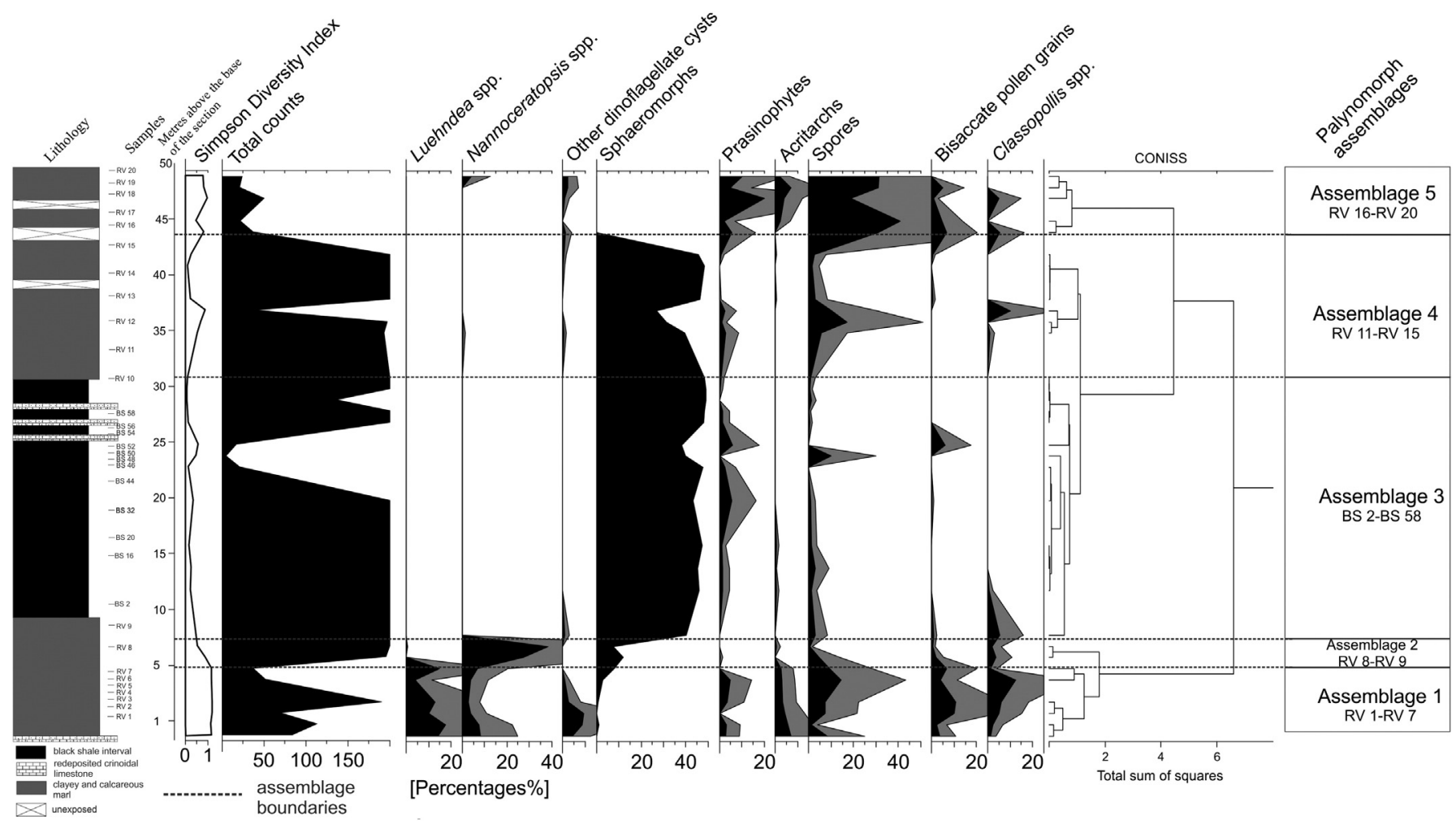

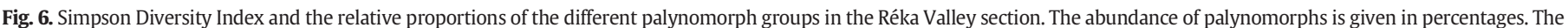

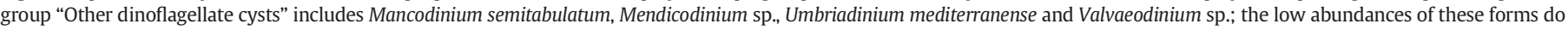
not permit their separate plotting. The lithological log on the left is not to scale. The grey shaded area has an exaggeration factor of $\times 2$.

2013). The Simpson Diversity Index was calculated only for the marine taxa because the reconstruction of terrestrial vegetation dynamics is beyond the scope of this study.

Correspondence analysis (CA) and detrended correspondence analysis (DCA) were also performed using the PAST software (Hammer et al., 2001). The square-root transformed data from the marine palynomorph counts were used, as palynological variables are similar to other biological variables and they are not normally distributed, so the standard deviations are often heterogenous (McDonald, 2014). CA and DCA were used to assess similarities between the samples studied to explore relationships between the different marine palynomorph groups (Hill and Gauch, 1980; Kovach, 1993). Special emphasis was placed on the co-occurrences of the different marine palynomorph groups to help identify palaeoecological changes (Correa-Metrio et al., 2014). A taxon abundance matrix was used for the input of data. The first and second axes are displayed both in the CA and DCA plot (Fig. 8). The advantage of DCA compared to other ordination methods is the elimination of the arch effect (Hill and Gauch, 1980; Hammer et al., 2001), and its relative insensitivity to differences in sample size (e.g. palynomorph counts) or diversity (De Toledo et al., 2009). The data matrix, eigenvalues, row and coloumn scores are available as online supplementary material.

Table 1

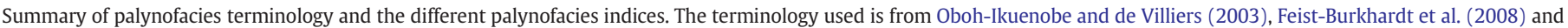
Götz et al. (2008).

\begin{tabular}{|c|c|}
\hline Sedimentary organic particles & Description \\
\hline Amorphous organic matter (AOM) & $\begin{array}{l}\text { Structureless, irregularly shaped, fluffy yellowish-brown to black masses that can be derived from the degradation of terrestrial or } \\
\text { marine organic matter }\end{array}$ \\
\hline Charcoal/black debris & Totally opaque particles with variable shape and size. They are derived from highly oxidised wood or other plant debris. \\
\hline Structured translucent plant debris & $\begin{array}{l}\text { Structured transparent particles with yellow-green to brown colour. They may be derived from degraded plant tissues or wood. They are } \\
\text { of various shape and size including lath-shaped and equidimensional particles. As cuticles are extremely scarce in the investigated } \\
\text { material, they were counted as part of this group. }\end{array}$ \\
\hline Spores & Male reproductive organs of bryophytes and pteridophytes \\
\hline Pollen grains & Male reproductive organs of the seed plants \\
\hline Marine palynomorphs & Dinoflagellate cysts, acritarchs, prasinophytes, sphaeromorphs and chitinous inner linings of foraminifera \\
\hline \multicolumn{2}{|l|}{ Palynofacies indices } \\
\hline $\mathrm{t} / \mathrm{m}$ index & $\begin{array}{l}\text { The } t / m \text { index quantifies the ratio of terrestrial }(t) \text { to marine }(\mathrm{m}) \text { palynomorphs, which reflects the vegetation of the hinterland and the } \\
\text { proportion of terrigenous input }\end{array}$ \\
\hline sp/bs index & The sp/bs index measures the ratio of spores (sp) to bisaccate pollen grains (bs) \\
\hline op/tr index & $\begin{array}{l}\text { The op/tr index quantifies the ratio of opaque (op) to translucent (tr) phytoclasts. It can indicate changes in the depositional } \\
\text { environment, as it reflects shifts between proximal and distal settings. }\end{array}$ \\
\hline bl/eq index & $\begin{array}{l}\text { The bl/eq index measures the ratio of bladed-lath shaped (bl) and equidimensional (eq) opaque phytoclasts, which also captures } \\
\text { proximal/distal trends. }\end{array}$ \\
\hline
\end{tabular}




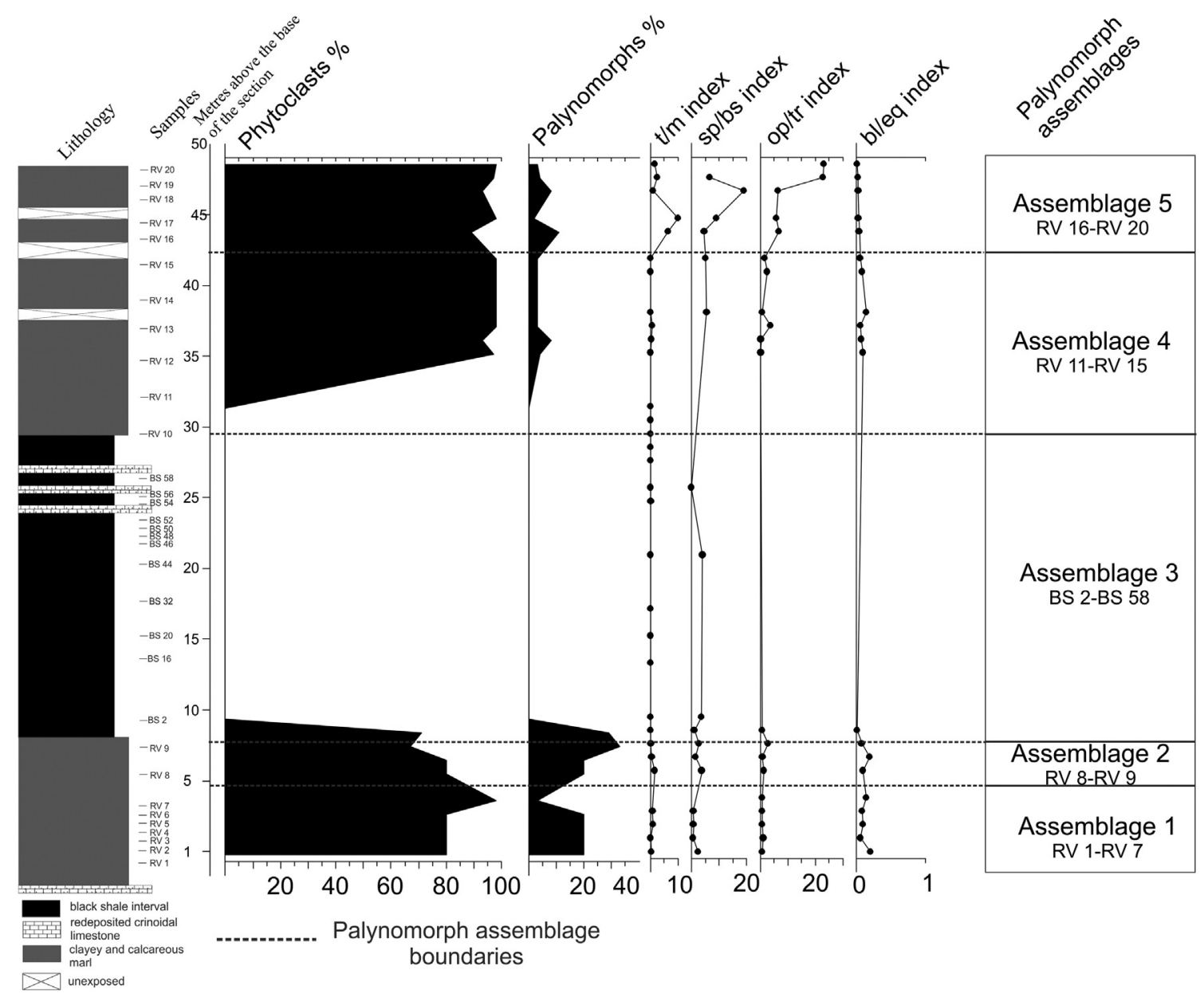

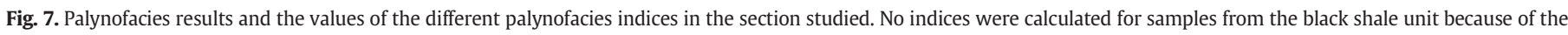

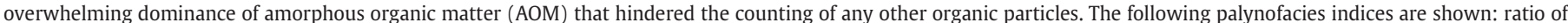

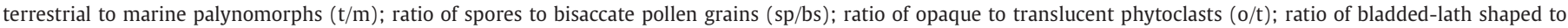
equidimensional opaque phytoclasts (bl/eq). The lithological log on the left is not to scale.

\section{Results}

\subsection{Palynology, palynofacies and diversity}

In this section, the palynomorph assemblages are described in detail. The marine palynomorphs are dominated by dinoflagellate cysts (Plate I). Terrestrially-derived palynomorphs include prominent bisaccate pollen, Classopollis sp., non-saccate gymnospermous pollen grains and trilete spores (Plate II). The spores were produced by ferns, lycopods and mosses, and belong to 19 genera. Cyathidites, the smooth trilete fern spore genus, is predominant. Ornamented forms are less frequent, although Ischyosporites variegatus and Manumia delcourtii are sporadically common. Bisaccate pollen is represented by Alisporites robustus, Alisporites cf. thomasii, Pityosporites sp. and Vitreisporites pallidus. Nonsaccate pollen, such as Cerebropollenites sp., Chasmatosporites spp., Monosulcites spp. and Spheripollenites psilatus, occur sporadically. The general characteristics of the sporomorphs are similar to other late Pliensbachian to early Toarcian assemblages from Europe (Van Erve, 1977; Lund and Pedersen, 1984; Guy-Ohlson, 1986; Dybkjær, 1991; Bucefalo Palliani, 1997). Acritarchs occur throughout, although they are low in both abundance and diversity; only three genera were recognised. Four prasinophyte taxa were distinguished, these include small (10$15 \mu \mathrm{m}$ in diameter), thin-walled, spherical palynomorphs, referred to as sphaeromorphs, and are characteristic of the black shale samples (Plate III). These have been referred to the prasinophyte species Halosphaeropsis jurassica by, for example, Bucefalo Palliani and Riding (2000). On the basis of changes in palynomorph diversity/composition and palynofacies, five assemblages were distinguished using cluster analysis (Fig. 6) and these are described below.

\subsubsection{Assemblage 1 (samples RV 1 to RV 7)}

In this interval, marine palynomorphs are more abundant than spores and pollen. The terrestrial/marine ( $t: m)$ index is $<1$ except in RV 6, where it reaches 1.69 (Figs. 6, 7). The dinoflagellate cyst genus Luehndea is dominant. Luehndea cirilliae and L. spinosa (Plate I, 12) are frequent, whereas L. microreticulata (Plate I, 9, 10) is rare. Other dinoflagellate cysts such as indeterminate forms, Mancodinium semitabulatum, Mendicodinium spp., Umbriadinium mediterranense and Valvaeodinium spp. are relatively rare. Prasinophytes and sphaeromorphs are minor constituents (3-6\%). The Simpson Diversity Index is approximately 0.8 , indicating a relatively even species distribution within the phytoplankton (Fig. 6). In the terrestrial fraction, gymnospermous pollen grains are dominant and the kerogen is of mixed marine and terrestrial origin (Plate III, 5). Opaque phytoclasts are dominant ( $82.5 \%$ in average), and palynomorphs are subordinate (Fig. 7).

\subsubsection{Assemblage 2 (samples RV 8 and RV 9)}

Samples RV 8 and RV 9 are characterised by common Nannoceratopsis, which represents $99 \%$ of the dinoflagellate cysts and $66 \%$ of the total palynomorphs (Fig. 6). The Simpson Diversity Index falls to 0.3 , suggesting significant assemblage change (Fig. 6). Nannoceratopsis gracilis exhibits considerable intraspecific variability; some forms have prominent dorsal antapical horns and strongly reduced ventral antapical horns. Morphotypes 13 and 17 of Gocht (1964) are common. 

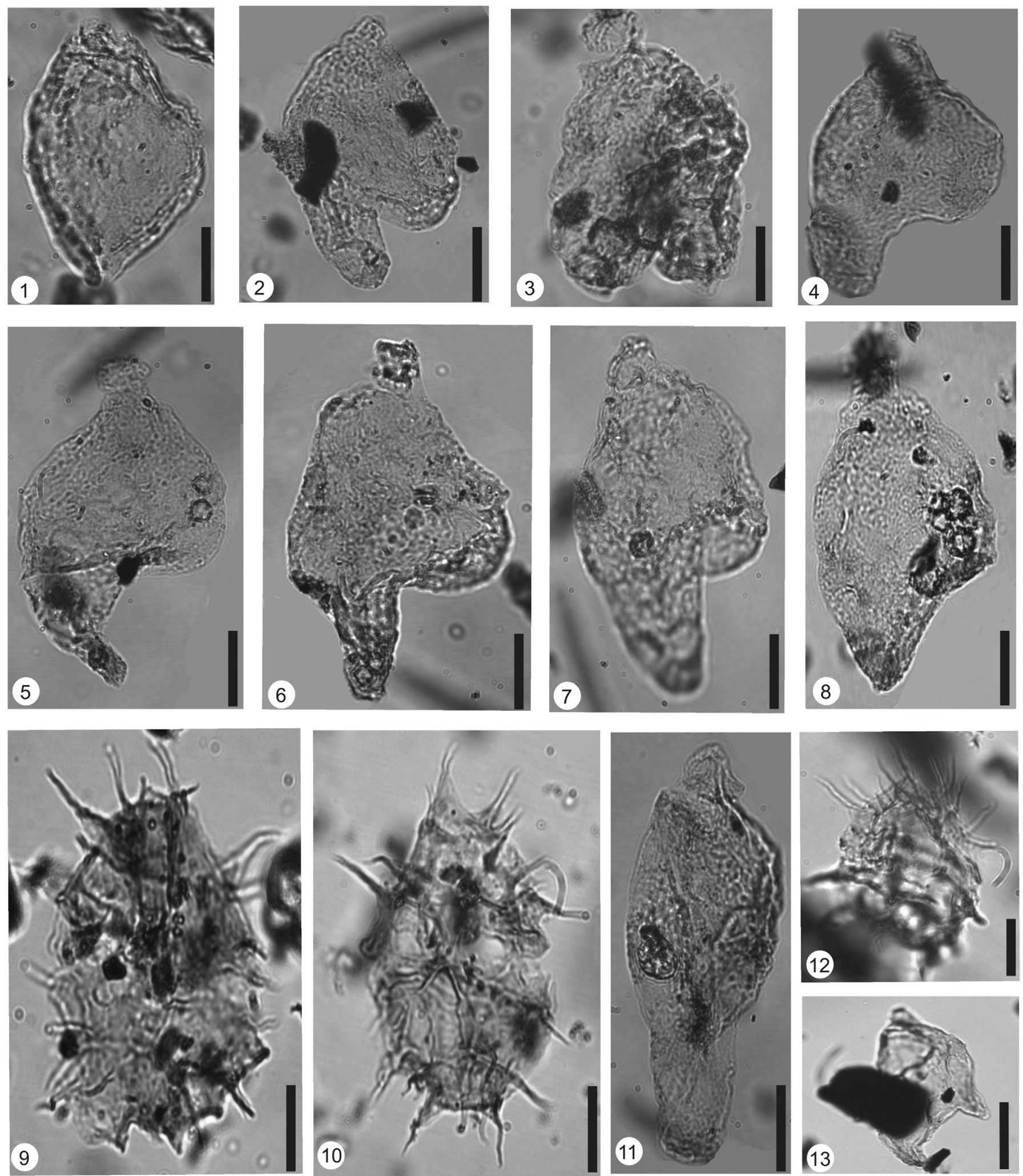

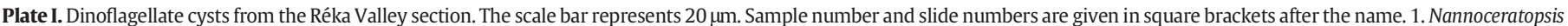

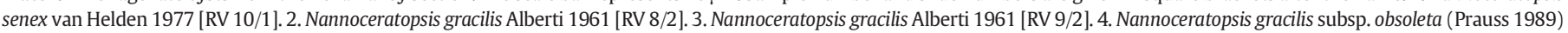

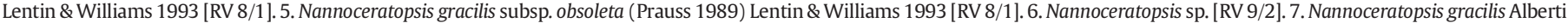

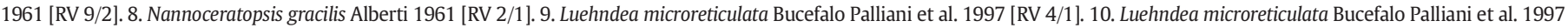

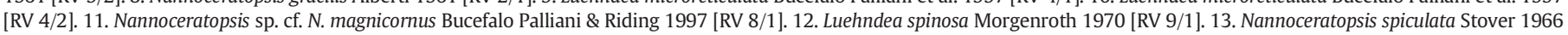
[RV 20/1]. 
These forms (Plate I, 4, 5) are similiar to $N$. gracilis subsp. obsoleta, which is characteristic in the early Toarcian of Germany (Prauss, 1989). Some specimens are close to N. magnicornus (e.g. Plate I, 11). A few forms with characteristic rectangular outlines bear prominent dorsal and reduced ventral antapical horns (Plate I, 6). Specimens with antapical horns of equal length are less frequent. Luehndea spinosa is present in RV 9, this is the stratigraphically highest occurrence of the species in this section. The range of this species is late Pliensbachian to earliest Toarcian, from the Pleuroceras spinatum to the D. tenuicostatum ammonite biozone (Bucefalo Palliani et al., 1997). The abundance of the sphaeromorphs increased. The t:m index is low, between 0.06 and 0.25 , but in the terrestrial fraction, the ratio of spores to bisaccate pollen is higher compared to Assemblage 1 (2.75 and 1.00 respectively) (Fig. 7). The relative proportion of trilete spores and Classopollis spp. to bisaccate pollen grains is higher than in Assemblage 1. Opaque phytoclasts of various shapes and sizes are the dominant kerogen maceral (Plate III, 6). Equidimensional and lath-shaped particles are both present (Fig. 7) and amorphous organic matter is absent.

\subsubsection{Assemblage 3 (samples BS 2 to BS 59)}

In the samples from the black shale, the abundance of all palynomorphs declined sharply except the sphaeromorphs which dominate this assemblage, comprising $93 \%$ of the total palynomorph assemblage (Fig. 6). The Simpson Diversity Index values are extremely low, ranging from 0.04 to 0.33 . Sample BS 32, with a relatively high Simpson Diversity Index, is characterised by a moderately high diversity of prasinophytes, including species of Tasmanites and sphaeromorphs. Other prasinophytes are Cymathiosphaera pachytheca, Leiosphaeridia sp. and Pleurozonaria polyporosa. The sphaeromorphs occur either as single grains, in chains, or in clusters (Plate III, 1, 2). Dinoflagellate cysts are virtually absent in this assemblage; a few poorly-preserved specimens were observed in sample BS 2 . Sedimentary organic matter is represented mostly by AOM (Plate III, 3,4 ). This is homogenous using plain transmitted light, but fluorescence reveals that the AOM commonly obscures phytoclasts, prasinophytes, sphaeromophs and sporomorphs (Plate III, 3). The fluorescence of the AOM is very weak, from pale brown to yellowish green, in marked contrast with the brightly fluorescent, yellow to green coloured palynomorphs and phytoclasts (Plate III, 3, 4).

\subsubsection{Assemblage 4 (samples RV 10 to $R V 15$ )}

The terrestrial fraction of Assemblage 4, in the beds immediately overlying the black shale, abruptly increases. In samples RV 11 to RV 15 the ratio of trilete spores, such as Cibotiumspora jurienensis, Concavisporites mesozoicus, Cyathidites spp., Dictyophyllidites harrisii and Ischyosporites variegatus, increases significantly, associated with abundant terrestrial phytoclasts (Figs. 6, 7). The spore/bisaccate pollen ratio ranges from 5.0 to 5.5. The microplankton assemblages are very sparse; acritarchs and dinoflagellate cysts are rare. Their scarcity may be due to the diluting effect of phytoclasts and sporomorphs. Dinoflagellate cysts are represented by rare Nannoceratopsis senex (Plate I, 1). Prasinophycean algae are common, and sphaeromorphs still occur in significant numbers (average 83\%). However, they show a decreasing trend from samples RV 10 to RV 12, and they do not occur in chains or clusters. The $\mathrm{t} / \mathrm{m}$ index remains low, as the sphaeromorphs are still common. Small aggregates of AOM are present in samples RV 13 to RV 15 , but it is absent in the rest of the samples. Translucent phytoclasts, which exhibit a great variety of colour, shape and size, are dominant in the kerogen assemblages (Fig. 7).

\subsubsection{Assemblage 5 (samples RV 16 to RV 20)}

The palynomorph spectrum from the uppermost assemblage is dominated by terrestrial input, hence the marine fraction is somewhat impoverished (Fig. 6). Dinoflagellate cysts comprise $\sim 4 \%$ of the marine palynomorphs throughout. The first occurrence of Nannoceratopsis spiculata (Plate I, 13) is in sample RV 20; this permits a correlation to the Hildoceras bifrons ammonite biozone (Riding and Thomas, 1992). The proportion of acritarchs (6\%) is higher than in Assemblage 4. The Simpson Diversity Index of the phytoplankton does not approach the levels of values Assemblages 1 and 2 (Fig. 6). Prasinophytes occur in significant numbers (21\%), but sphaeromorphs are absent. Sporomorphs dominate the assemblages, with spores being most abundant. The sporomorphs from Assemblages 4 and 5 are relatively conservative, however, the ratio of bisaccate pollen to trilete spores is higher in

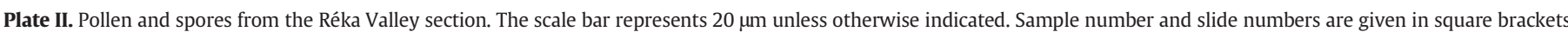
after the name.

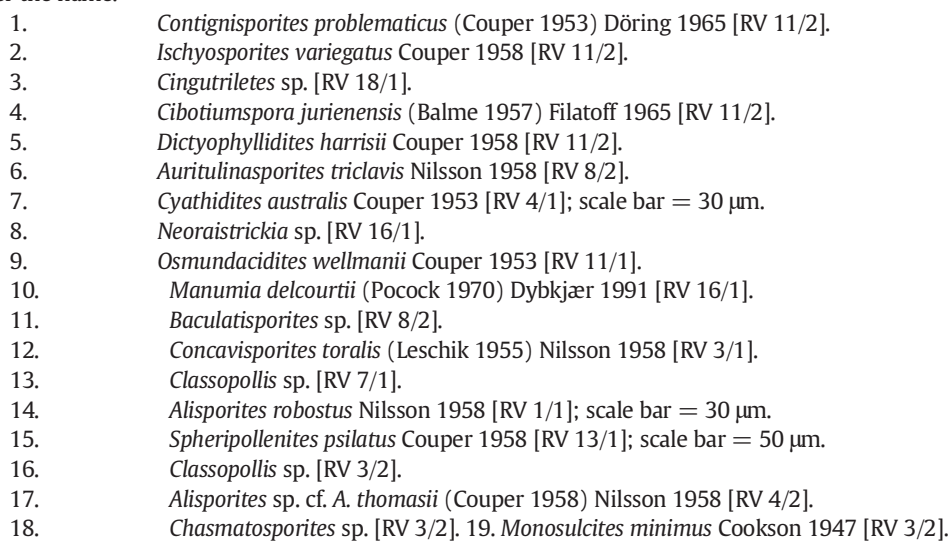

Plate III. Sphaeromorphs and representative palynofacies from the Réka Valley section. (see on page 12)

1. Sphaeromorphs in clusters. Sample BS 32; scale bar $=20 \mu \mathrm{m}$.

2. Sphaeromorphs in clusters. Sample BS 56; scale bar $=20 \mu \mathrm{m}$.

3. Fluorescence photomicrograph of amorphous organic material (AOM). The particles with higher fluorescence intensities are palynomorphs, the phytoclasts are masked by AOM; scale bar $=50 \mu \mathrm{m}$.

4. Palynofacies of Assemblage 3 with predominant AOM; scale bar $=100 \mu \mathrm{m}$.

5. Palynofacies of Assemblage 1 with predominant translucent phytoclasts; scale bar $=100 \mu \mathrm{m}$.

6. Palynofacies of Interval 2 with Nannoceratopsis sp. from Plate I, Fig. 6; scale bar $=100 \mu \mathrm{m}$.

7. Palynofacies of Interval 4 with high levels of translucent phytoclasts; scale bar $=100 \mu \mathrm{m}$.

8. Palynofacies of Interval 5 with predominant opaque, equidimensional phytoclasts; scale bar $=100 \mu \mathrm{m}$. 

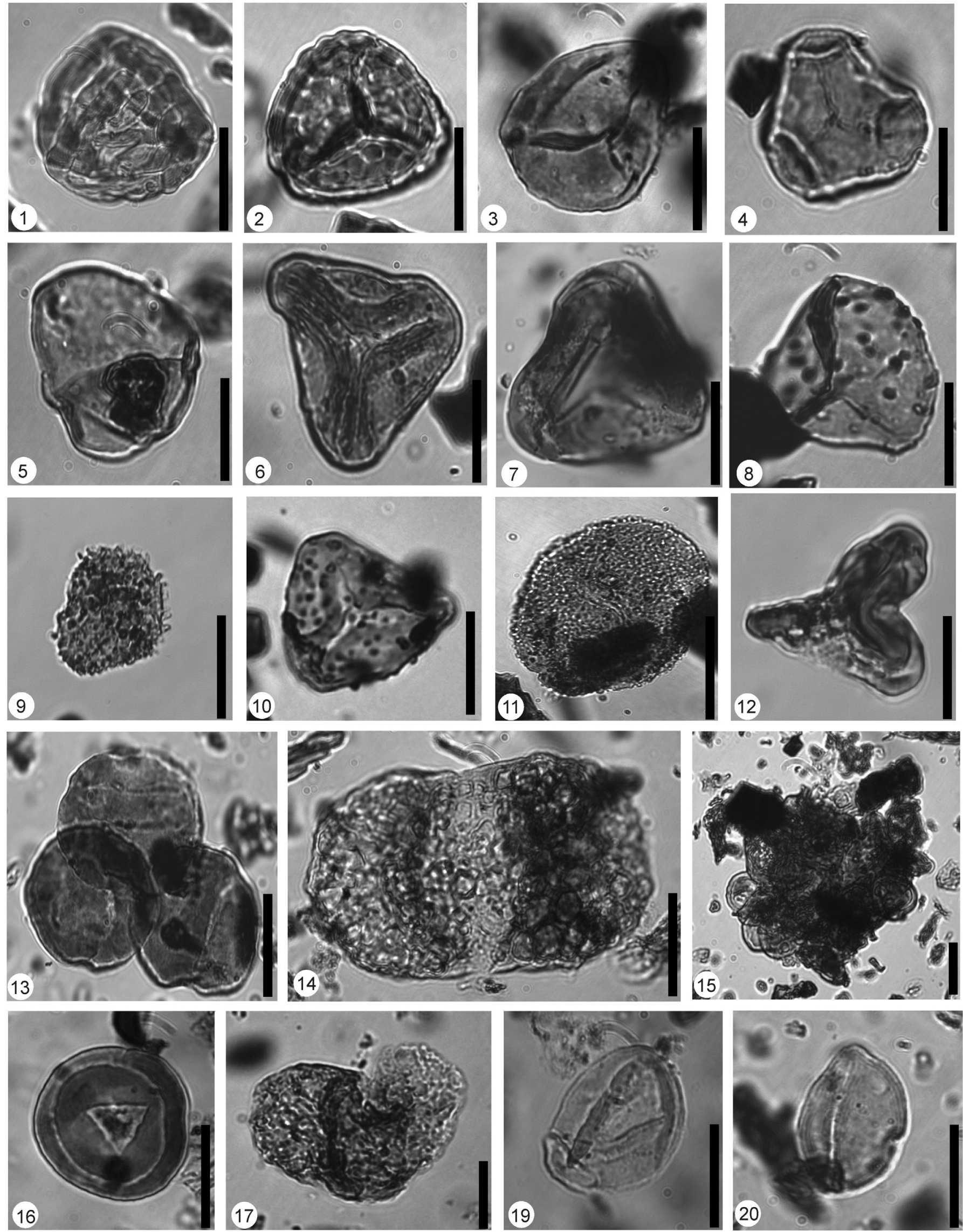

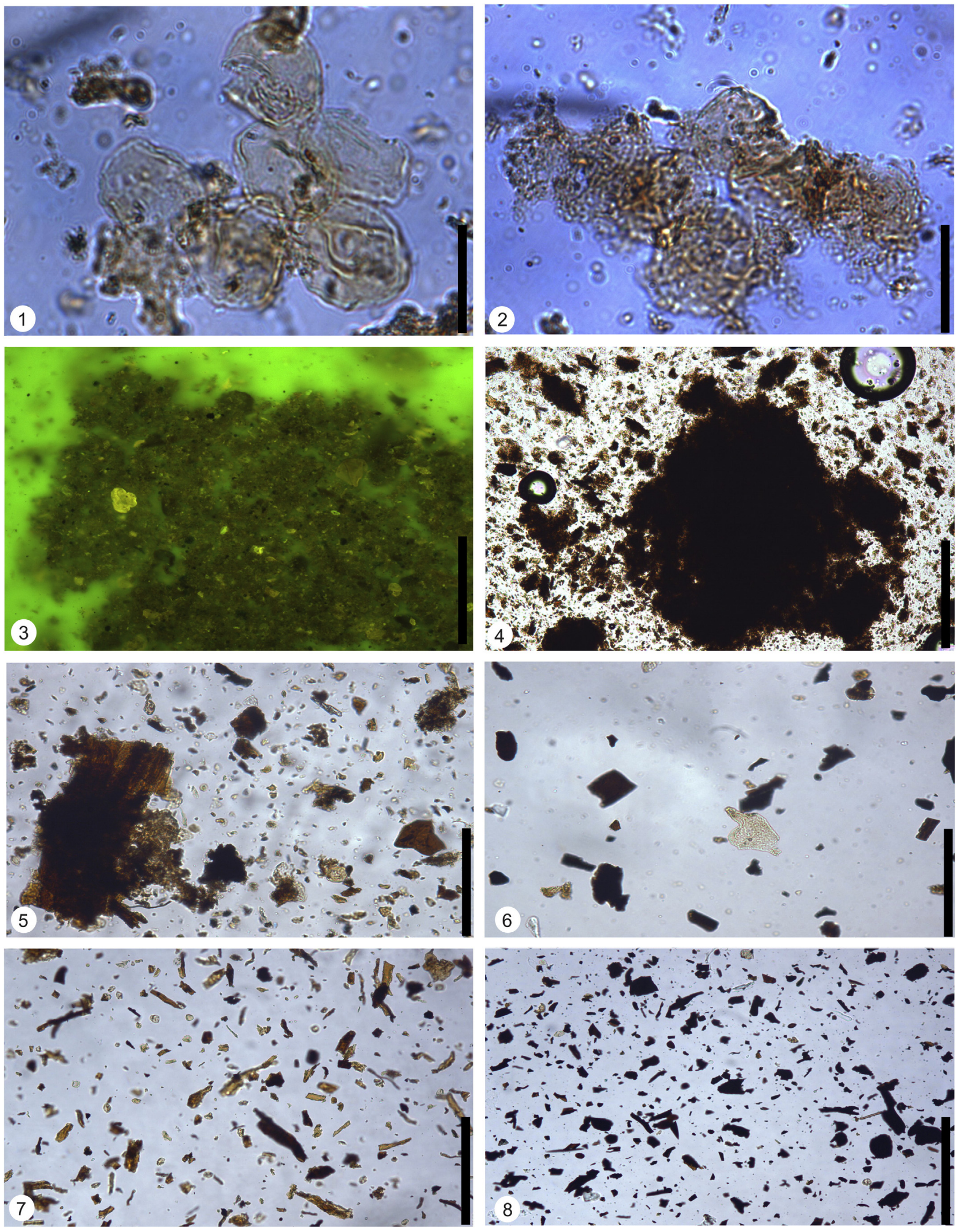
Assemblage 5 compared to Assemblage 4 (Figs. 6, 7). Palynofacies allows the two assemblages to be separated. Opaque, equidimensional phytoclasts increase in abundance, and AOM is absent throughout in Assemblage 5 (Plate III, 7, 8). The relative proportions of marine material are higher than in Assemblage 4, but the $t / m$ index is also high with an average of 4.3 , reflecting the impoverished phytoplankton communities.

\subsection{Multivariate statistical analysis}

To analyse the palaeoecological signals which controlled the succession of palynomorph assemblages, multivariate ordination methods, correspondence analysis (CA) and detrended correspondence analysis (DCA) were performed on the palynomorph data (Fig. 8). Using CA, Axis 1 elucidates $58 \%$ of the total variance within the dataset, whereas
Axis 2 carries an additional 24\% of the variance (Fig. 8A). In the DCA analysis, the elimination of the arch effect by division of the ordination into segments distorts the variance fractions. Therefore the eigenvalues of the different axes cannot be interpreted as variance fractions (Hill and Gauch, 1980; Legendre and Legendre, 1998). The eigenvalues, by contrast, reflect the relative importances of the different axes (Legendre and Legendre, 1998; Correa-Metrio et al., 2014), and higher values account for more variance within the data. In this case Axis 1 is similar to the CA plot with an eigenvalue of 0.5842 , compared to the significantly lower eigenvalue of 0.1638 for Axis 2 (Fig. 8B).

In both the CA and DCA scatter plots, four major groups of samples are distinguished (Fig. 8). These generally correspond to the palynomorph assemblages established herein, except that Assemblages 3 and 4 could not be separated due to the predominance of sphaeromorphs. Assemblages 1 and 3-4 are strongly polarised in both

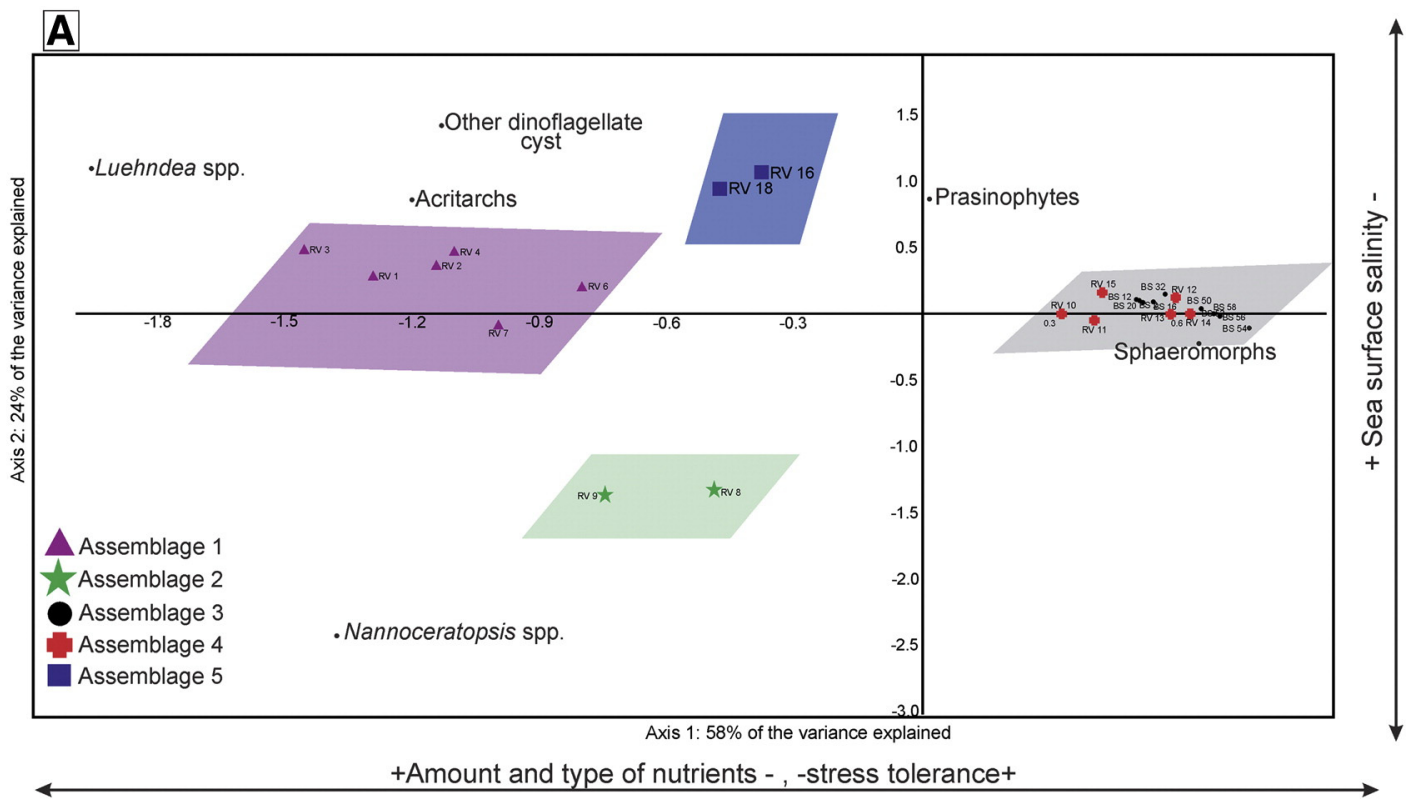

B

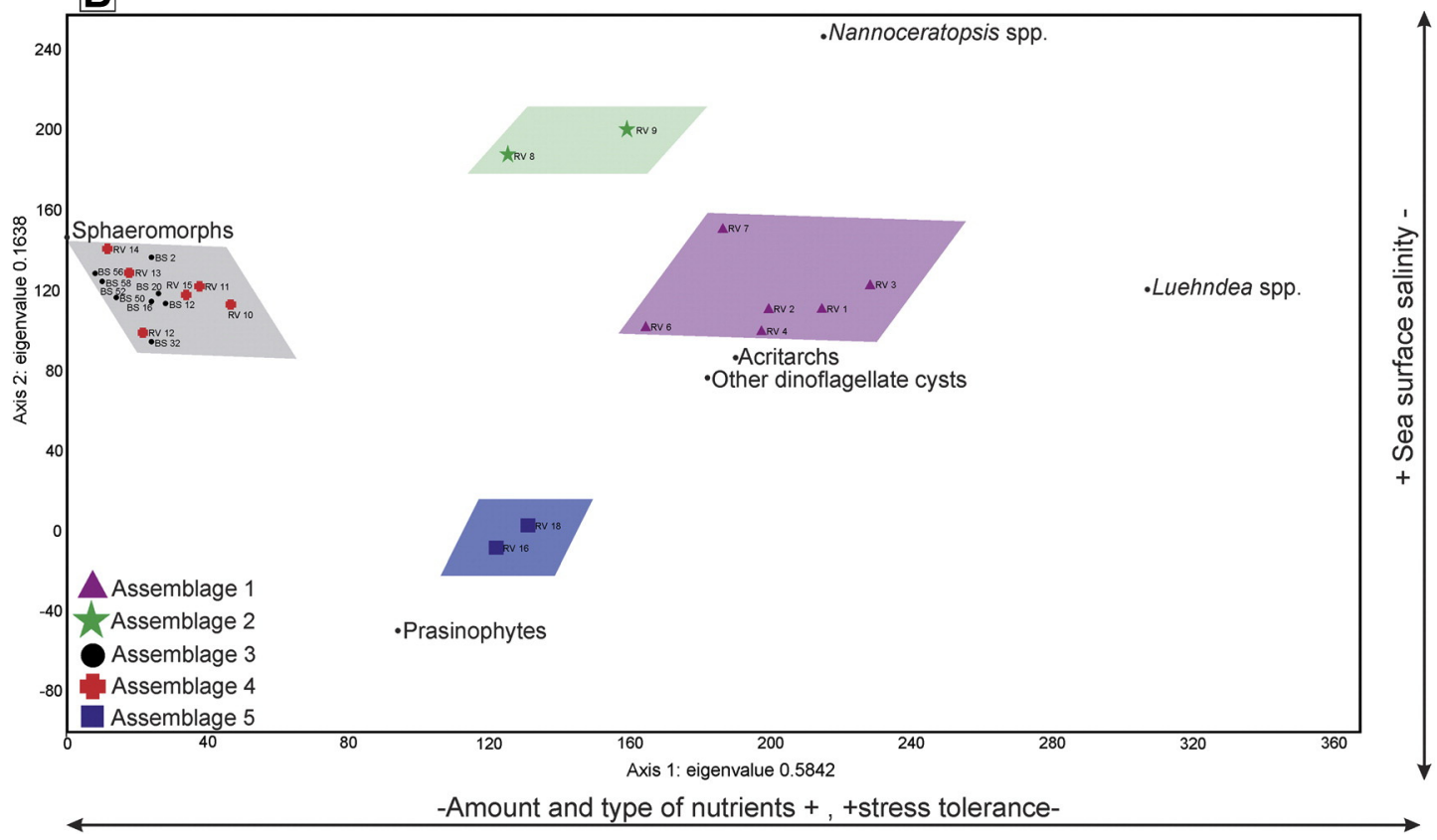

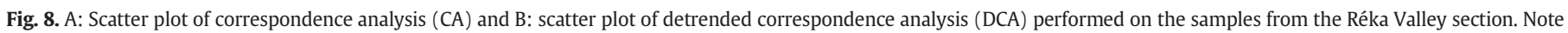
palaeoecologically controlled differences among the palynomorph assemblages. See text for details. 
plots along Axis 1 (Fig. 8). The similarity of Assemblages 1 and 5 is demonstrated by their proximity in the plots, but they exhibit clear separation from Assemblage 2 (Fig. 8).

\section{Discussion}

\subsection{Successive change of the phytoplankton communities}

The palynological analyses of the Réka Valley section indicate that the phytoplankton communities responded to the palaeoenvironmental stress associated with the T-OAE by the successive replacement of characteristic assemblages. In order to explore this further, the succession was divided into five palynomorph assemblages (Fig. 6) which represent distinct intervals during the progression of this major palaeoenvironmental perturbation. These intervals reflect changes in the paleocommunities that can be interpreted using the framework of four successive stages recognised in modern ecosystems affected by hypoxia. These include: (0) severely disturbed communities; (1) disturbed communities; (2) transitional communities; and (3) undisturbed, climax communities (Diaz and Rosenberg, 2008). Three of these (communities 0 to 2) are unequivocally present in the Réka Valley succession, and are described below.

\subsubsection{Interval 1}

The most abundant dinoflagellate cysts, Luehndea spinosa and Nannoceratopsis gracilis, are interpreted as being opportunistic species, which may have favoured elevated nutrient levels as a result of high terrigenous input (Bucefalo Palliani and Riding, 1997a, 1997b, 2000). The assemblage in Interval 1 has the highest Simpson Diversity Index values (0.7-0.85) within the entire succession (Fig. 6). Interval 1 represents a transitional phase (community 2 of Diaz and Rosenberg, 2008) from an undisturbed, climax community to a disturbed association (Assemblage 2). This is manifested by an increasing number of opportunistic species, and higher bioproductivity. A true undisturbed, climax community (community 3 of Diaz and Rosenberg, 2008) was not encountered in the succession studied, because all the assemblages were characterised by moderate to low diversities, and high abundances.

A warm, humid palaeoclimate and significant riverine influx are inferred from the presence of spores such as Cibotiumspora juriensis, Cyathidites spp., Dictyophyllidites harrisii, Ischyosporites variegatus, Manumia delcourtii, Neoraistrickia sp. and Uvaesporites argentaeformis. These were often associated with riverine settings or, warm and wet marsh environments (Abbink et al., 2004). Additionally, spore spikes are often associated with global warming, acceleration of the hydrological cycle and carbon cycle perturbation as demonstrated for the endTriassic event (Bonis et al., 2009). The strong heterogeneity of phytoclasts (e.g. brown wood, charcoal, cortex, cuticle fragments and membranous tissues), shape and size (Fig. 7) is also explained by intense riverine input resulting from enhanced runoff from the hinterland (Dybkjær, 1991). The Réka Valley section had a more distal depositional setting compared to Denmark, Germany or the UK and there is no evidence for sea-level drop in the early Toarcian that could have contributed to increased terrestrial input (Galácz, 1991). Therefore the high phytoclast counts and the heterogeneity of the group are assigned to increased runoff rather than shorter transport or prioximity of the hinterland.

This scenario is consistent with the ongoing global warming and increasing humidity, intensification of continental weathering and enhanced runoff from the hinterland during the early Toarcian (McElwain et al., 2005; Dera et al., 2009). The shift towards increased humidity, continental weathering and runoff is also supported by the high kaolinite content in the clay mineral spectrum of the Réka Valley succession (Raucsik and Varga, 2008a, 2008b). The absence of AOM indicates ventilated, well-oxygenated bottom conditions and vertical mixing of nutrients in the water column. In summary, strong terrestrial influence and eutrophic conditions are inferred from the palynofacies and the palynomorph distribution in Interval 1.

\subsubsection{Interval 2}

The abundance of Nannoceratopsis spp. in Interval 2 indicates significant disturbance of the phytoplankton communities. The opportunistic, euryhaline character of this genus (Riding, 1983, 1984, 1987; Riding et al., 1985) readily allows adaptation to lower salinity conditions in the surface waters caused by increased freshwater input. The low Simpson Diversity Index values (0.3-0.5) (Fig. 6) also suggest that this assemblage represents a disturbed community (community 1 of Diaz and Rosenberg, 2008). Several aberrant morphotypes of Nannoceratopsis gracilis occur in Interval 2. Some of these are similar to $N$. magnicornus (see Bucefalo Palliani and Riding, 1997a); others resemble N. gracilis subsp. obsoleta (see Prauss, 1989). However, others exhibit a rectangular outline and one prominent dorsal antapical horn (Plate I, 6.). These morphotypes are confined to Interval 2. In Interval 1, Nannoceratopsis is represented by different species. The appearance of these unusual forms is indicative of stressed palaeoenvironments, and represents the reaction of this genus to lower surface water salinity and/or changes in oxygen and nutrient availability. According to Bucefalo Palliani and Riding (2000), these unusual morphological features of Nannoceratopsis reflect the differing tolerance levels of the species. Nannoceratopsis magnicornus did not survive the anoxic phase in England, France and Hungary, whereas N. gracilis and N. senex are still present in higher stratigraphical levels at these localities. It is difficult to determine the adaptational advantages or disadvantages of the morphological features of $N$. gracilis, N. magnicornus or $N$. senex. The main control was probably the relationship of size, shape and weight of the cysts to the buoyancy and hydrodynamic forces in stratified water bodies. Evitt (1961) pointed out the huge intraspecific morphological variability of $N$. gracilis, and we suggest that the aberrant forms herein are all different morphotypes of $N$. gracilis. Additionally, studies on many modern dinoflagellates have shown that salinity exerts a strong control on the morphology of their cysts (Ellegaard, 2000; Rochon et al., 2009; Mertens et al., 2012; Verleye et al., 2012). Intringuingly, Evitt (1961) and Gocht (1972) pointed out the similarities of the epicystal tabulation pattern between peridinoid dinoflagellates and Nannoceratopis. Although Nannoceratopsis belongs to a separate order of dinoflagellates (Fensome et al., 1993) without any modern descendants, it cannot be entirely excluded that they had similar lifestyles to modern peridinoid heterotrophic dinoflagellates (Evitt, 1961), thereby explaining their high productivity and prevalence in eutrophic water masses.

\subsubsection{Interval 3}

The increased freshwater supply during Intervals 1 and 2 led to the establishment of a stable and stratified water column with dysoxic, or anoxic, conditions at the sea bed and in the water column. The onset of black shale sedimentation is coeval with a sharp reduction in phytoplankton diversity. The severe disturbance of the phytoplankton communities is manifested by the low Simpson Diversity Index, which dropped from $0.3-0.5$ to $0.05-0.2$ (Fig. 6). This assemblage represents a severly disturbed community (community 0 of Diaz and Rosenberg, 2008). The low salinity, oxygen-poor and subsequently oligotrophic conditions were only tolerated by some phytoplankton groups. Sphaeromorphs, which dominate the marine palynomorph spectrum, were previously believed to belong to several groups (e.g. green algae, pollen), and their affinity still remains uncertain (Bucefalo Palliani et al., 2002; Van de Schootbrugge et al., 2005b, 2013). According to Prauss and Riegel (1989), their affinity is probably the Prasinophyceae, a primitive group of Chlorophyta. This is corroborated by their common co-occurrence with prasinophyte phycomas (Van de Schootbrugge et al., 2013). The sphaeromorphs, together with other prasinophytes, are the only phytoplankton groups that could have survived significant freshening of the surface waters. Alternatively, they could withstand periods when dysoxic-anoxic, probably even euxinic, conditions reached 
the photic zone. Furthermore, they were better adapted to the reduced recycling of nutrients that sank to the bottom, and could not return to the photic zone due to density stratification of the water column (Farrimond et al., 1989; Prauss, 2007).

The extension of the oxygen minimum zone severely affected the dinoflagellate cyst assemblages. Studies on modern dinoflagellates have proved that oxygen availability exerts a strong control on excystment, and anoxic conditions completely prohibit the successful germination of the cysts (Anderson et al., 1987; Pross, 2001). This led to the temporary disappearance of dinoflagellates, a 'blackout' event (Loh et al., 1986).

The abundance of AOM and a lack of bioturbation indicate oxygen deficiency at the sediment-water interface. This lead to the deposition of finely laminated, organic-rich black shales. The kerogen in the black shale consists mainly of marine organic material of algal origin (liptinite), with $<10 \%$ terrestrial components (vitrinite and intertinite) (Varga et al., 2007). However, fluorescence analysis reveals that the AOM masks many sporomorphs and phytoclasts. The temporary presence of euxinic conditions during the deposition of the black shale in the Réka Valley is manifested by the presence of micrometre-scale pyrite framboids in the black shale. The episodic return of oxygenated conditions is suggested by sparse bivalves in the black shale (Galácz, 1991). However, based on the estimates of Röhl and Schmid-Röhl (2005) from the Posidonia Shale, these episodes may have lasted only few months or years.

Such a characteristic association of abundant sphaeromorphs and AOM, together with the lack of dinoflagellate cysts, is widely recognised from the lower Toarcian black shale facies in northwest Europe (Wall, 1965; Wille, 1982; Lund and Pedersen, 1984; Prauss and Riegel, 1989; Dybkjær, 1991; Prauss et al., 1991; Bucefalo Palliani et al., 2002). The dinoflagellate cyst diasappearance extends from the upper part of the $D$. tenuicostatum to the $H$. falciferum ammonite biozones. The prasinophytes are considered to be 'disaster taxa' because of their peaks in the near absence of other phytoplankton groups such as dinoflagellates (Van de Schootbrugge et al., 2005b). However, the reasons for their proliferation during anoxic events, including their widespread distribution at the T-OAE, are still controversial. Prauss (2007) summarised the probable causes of prasinophyte abundance during anoxic events (e.g. the T-OAE and the Cenomanian/Turonian event). He suggested that the low salinity of surface waters and the extension of the oxygen minimum zone alone cannot account for the turnover in the phytoplankton communities. Furthermore, the availability of trace elements $(\mathrm{Cu}, \mathrm{Fe}, \mathrm{Mn}, \mathrm{Mo}, \mathrm{Zn})$ and nutrients $(\mathrm{N}, \mathrm{P})$ may exert a larger control on different algal groups (Falkowski et al., 2004; Katz et al., 2004). In addition, the prasinophyte abundance may also be connected to the denitrification of the water column (Jenkyns et al., 2001).

\subsubsection{Intervals 4 and 5}

The return of bioturbated sediments, such as marls with increasing carbonate content upsection, in the upper part of the section marks the end of the anoxic event, and the re-establishment of an oxygenated water column. However the phytoplankton communities were not yet fully recovered, and represent a disturbed, transitional community to climax assemblages (community 2 of Diaz and Rosenberg, 2008). The Simpson Diversity Index of the phytoplankton continued to remain low (Fig. 6). The Lazarus effect (Wignall and Benton, 1999) is a common feature among the dinoflagellate cysts returning in this interval, because there are many species which reappeared after the event. The adaptation of Nannoceratopsis to a more proximal setting with lower salinities may have favoured their survival during the T-OAE. They probably used proximal settings as refugia. Prauss (1996) suggested they could thrive in nearshore palaeoenvironments due to their euryhaline nature (Riding, 1983, 1984, 1987)

This interval is also characterised by an increase of fern spores, whereas other terrestrial palynomorphs occur only in low proportions. This indicates humid and warm palaeoclimatic conditions. Sparse dinoflagellate cysts (e.g. $N$. senex) and acritarchs occur, and sphaeromorphs are still present. The absence of AOM indicates a ventilated, non-stratified water column. The palynofacies is dominated by cuticles, elongated (blade-like) phytoclasts and plant tissues indicating either proximity to the shoreline, intense runoff or both. In Interval 5, sphaeromorphs further declined, and the palynofacies patterns indicate an unstable water column with ventilated conditions. The abundance of predominantly rectangular, small opaque phytoclasts indicates a deepening trend in the late Toarcian of the Mecsek Basin which is consistent with basin evolution in this area (Csontos and Vörös, 2004).

\subsection{Multivariate statistical analysis and palynomorph community change}

A key feature of the scatter plots is the grouping and polarisation of samples along both axes. The fact that changes along Axis 1 account for the majority of variance in the dataset, both in CA and DCA (Fig. 8), implies that the underlying palaeoenvironmental parameter was the main driver of the community replacement of organic-walled microplankton. This is also suggested by the marked difference in the axis scores of dinoflagellate cysts and acritarchs compared to those of sphaeromorphs and prasinophytes (online supplementary material). The similar values for prasinophytes and sphaeromorphs on both axes in the CA and DCA plots indicate a possible relationship, as proposed by Prauss and Riegel (1989), Bucefalo Palliani et al. (2002) and van de Schootbrugge et al. (2005b, 2013). Among the dinoflagellate cysts, Luehndea and Nannoceratopsis favoured high nutrient levels, approaching eutrophic conditions (Bucefalo Palliani and Riding, 1999a). However, Luehndea differs from Nannoceratopsis in its lower tolerance of reduced surface salinities. Nannoceratopsis is known to be a euryhaline genus, which could have tolerated low surface salinities (Riding, 1983, 1984, 1987; Riding et al., 1985; Prauss, 1996). Samples from Assemblage 1 with high proportion of Luehndea plot closer to samples with acritarchs and other dinoflagellate cysts along Axis 1, indicating similar palaeoecological preferences and a more diverse community compared to other intervals. Favourable conditions, ventilated bottom waters and sufficient amount of nutrients are inferred, whereas Assemblages 3 and 4 indicate severe palaeoenvironmental deterioration, i.e. changes in surface water salinity and/or nutrient and oxygen availability. The position of the groups along Axis 1 suggests that it reflects a gradient of stress tolerance of the phytoplankton groups, most likely against adverse changes in nutrient availability in the water column. The assemblages reflect a shift from the eutrophic conditions preferred by Luehndea and Nannoceratopsis (Bucefalo Palliani and Riding, 1999a), to oligotrophic conditions with proliferation of sphaeromorphs due to the establishment of a stratified water column (Bucefalo Palliani and Riding, 1999a; Bucefalo Palliani et al., 2002). This gradient may also reflect changes in the type of nutrients available, because green algae (prasinophytes, sphaeromorphs) and dinoflagellates have different nutrient preferences (Falkowski et al., 2004). Additionally, the prevailing hypoxic-anoxic conditions and the probable denitrification of the water column during the T-OAE (Jenkyns et al., 2001) could have favoured the 'disaster taxa' such as the prasinophytes (Van de Schootbrugge et al., 2005b, 2013). This also corroborates the hypothesis of Prauss (2007) that low salinity surface waters and oxygen deficiency in the water column alone cannot account for the abundance of the sphaeromorphs during the T-OAE, and that the availability or lack of distinct nutrients exerted a strong control on phytoplankton turnover patterns.

Axis 2 in CA and DCA with the second highest eigenvalues represents another environmental parameter important for the community replacement, which is interpreted here as surface water salinity. Its gradient ranges from normal marine to low salinity surface water, the latter deriving from enhanced riverine freshwater influx. This interpretation is supported by the markedly different scores of the euryhaline genus Nannoceratopsis and the other groups on Axis 2 (Fig. 8). This signal may be influenced by the palaeogeographical setting of the Mecsek Basin, as freshwater delivery is only significant in depositional settings 
close to the continental hinterland, and negligible in the Tethyan open oceanic areas.

\section{Palynostratigraphy}

The succession of palynomorph assemblages is also useful for establishing the biostratigraphy of the Réka Valley section. This mainly based on species of the dinoflagellate cyst genera Luehndea and Nannoceratopsis. The Jurassic dinoflagellate cyst biozonation for northwest Europe was developed by Woollam and Riding (1983), Prauss (1989), FeistBurkhardt and Wille (1992), Poulsen (1992), Riding and Thomas (1992) and Poulsen and Riding (2003). The latter zonal scheme can be applied to the the Réka Valley section, where two dinoflagellate cyst zones can be distinguished. Assemblages 1 and 2 correspond to Zone DSJ7 of Poulsen and Riding (2003), correlated with the D. tenuicostatum ammonite biozone. The base of this zone is defined by the range tops of Maturodinium inornatum and Valvaeodinium armatum, whereas the top is marked by the apparent extinction of Luehndea spinosa. Maturodinium inornatum and Valvaeodinium armatum were not recovered here, but the last occurrence of L. spinosa is in sample RV 9. The stratigraphical range of Luehndea extends higher, because Luehndea cirillae has been reported from the H. falciferum ammonite biozone (Baldanza et al., 1995; Bucefalo Palliani et al., 1997; Bucefalo Palliani and Riding, 1999b). Assemblage 3 from the black shale unit lacks any age diagnostic dinoflagellate cyst species, but Assemblages 4 and 5 yielded several specimens of Nannoceratopsis, indicative of Zone DSJ8 of Poulsen and Riding (2003), and correlated with the H. falciferum and H. bifrons ammonite biozones.

\section{Correlation and comparison with other lower Toarcian black shale localities}

To elucidate regional and global trends in biotic turnovers in organic-walled phytoplankton communities, four localities were selected for comparison with the five stage floral replacement pattern observed in the Réka Valley section (Fig. 9). The Brown Moor borehole in Yorkshire, UK (Bucefalo Palliani et al., 2002), the Bisingen/Zimmern borehole in southwest Germany (Prauss et al., 1991) and the Grimmen section in northwest Germany (Prauss, 1996) represent the Northwest European Province. From the Mediterranean Province of the Tethyan Realm, successions from the Umbria-Marche Basin in central Italy are used (Bucefalo Palliani et al., 1998; Bucefalo Palliani and Riding, 1999a). In addition, the Quercy section in southwest France was chosen for comparison due to its transitional position between the epicontinental northwest European and the more open marine Mediterranean regions (Bucefalo Palliani and Riding, 1997a). The characteristic palynological features and the biotic events inferred at these localities are summarised in Fig. 9.

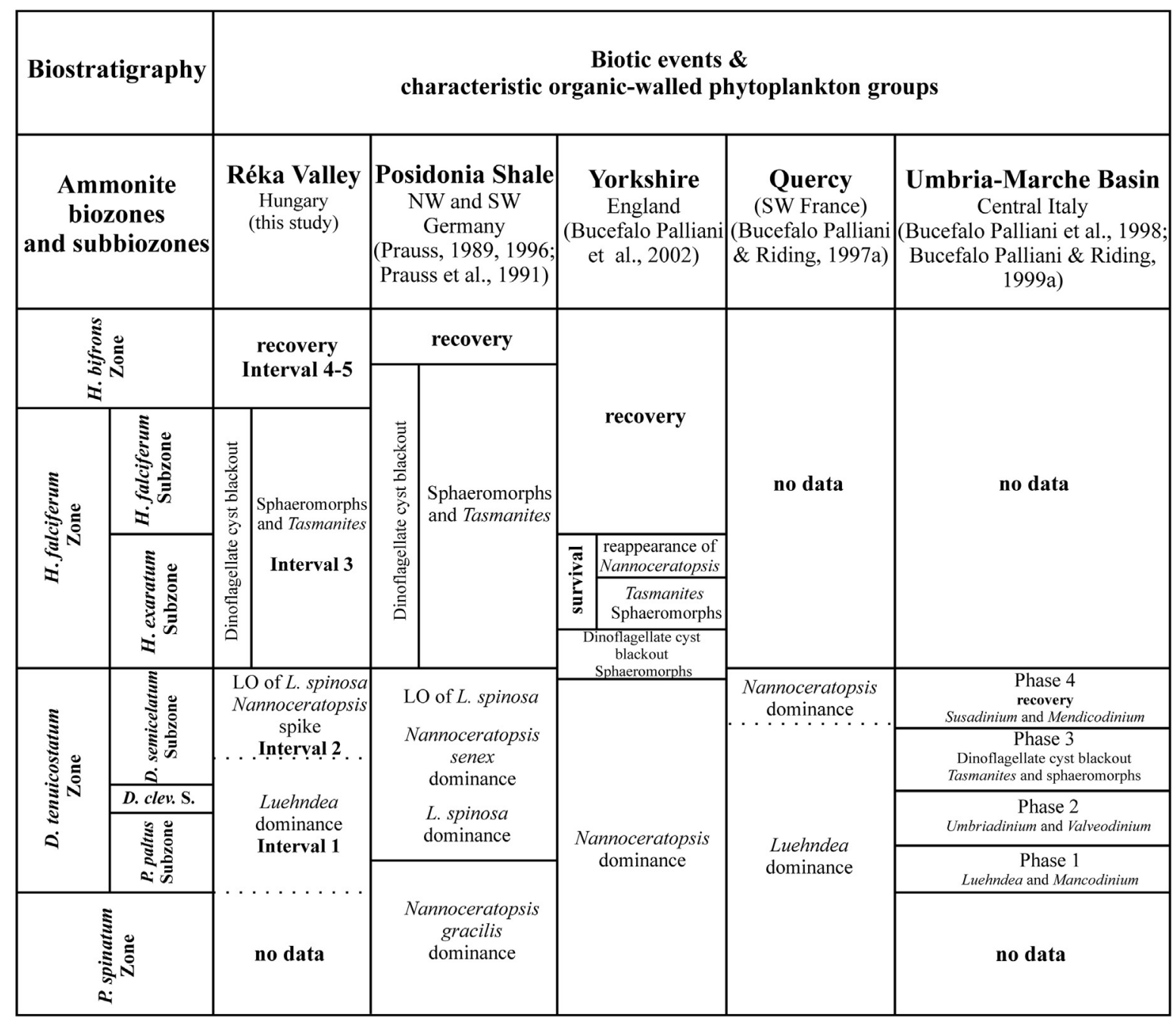

... . biostratigraphical assignment uncertain

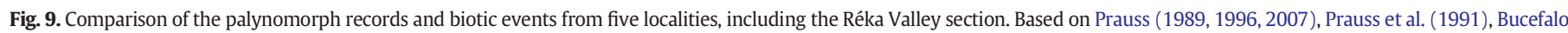
Palliani and Riding (1997a, 1999a) and Bucefalo Palliani et al. (1998, 2002). 


\subsection{Comparison with northwest Europe}

Marine palynomorphs in the lower Toarcian of northwest Europe are dominated by Luehndea spinosa, Mancodinium semitabulatum, Nannoceratopsis spp., sphaeromorphs and Tasmanites spp. (Bucefalo Palliani and Riding, 1999b, 2003a). The Réka Valley assemblages are entirely consistent with this. In North Yorkshire, dinoflagellate cysts are gradually replaced by prasinophytes and sphaeromorphs, resulting in a dinoflagellate cyst blackout event coincident with the negative carbon isotope excursion and the TOC maximum between the Dactylioceras semicelatum and Harpoceras exaratum ammonite subbiozones (Bucefalo Palliani et al., 2002). By contrast, at Réka Valley, the replacement of dinoflagellate cysts by prasinophytes is sudden rather than gradual, although this may be partly attributed to different sampling resolutions. The duration of the phytoplankton disappearance event and the stratigraphical range of the sphaeromorphs are also longer at Réka Valley.

In the Posidonia Shale of southwest Germany the relative proportions of Nannoceratopsis senex increases gradually in the upper part of the $D$. tenuicostatum ammonite biozone to the onset of the bituminous facies, which is comparable to Interval 2 in the Réka Valley section (Fig. 9). The black shale interval in the Posidonia Shale is also devoid of dinoflagellate cysts, similar to Interval 3 at Réka Valley. However, at Grimmen in northwest Germany, Nannoceratopsis is present throughout the organic-rich facies (Prauss, 1996). This is due to the more proximal depositional setting and persumabily more effective circulation within the water column at Grimmen, that provided refuge for Nannoceratopsis. After the T-OAE, the dinoflagellate cysts returned in the upper part of the $H$. bifrons ammonite biozone in southwest Germany (Prauss et al., 1991). However, they are less abundant and diverse than before the anoxic event, which is similar to the low phytoplankton levels in Intervals 4 and 5 at Réka Valley. Another similarity between Réka Valley and southwest Germany is the abundance of pollen and spores, together with terrestrial kerogen such as huminite and vitrinite, in the pre-event beds in the $P$. spinatum to $D$. tenuicostatum ammonite biozones (Fig. 9). The replacement of phytoplankton, and the length of the disappearance event, were more pronounced in Germany and the Réka Valley compared to Yorkshire (Fig. 9; Wall, 1965; Prauss and Riegel, 1989; Bucefalo Palliani et al., 2002).

The Quercy succession in southwest France yields similar assemblages to those further north in Europe and the Réka Valley. Luehndea spinosa is dominant in the D. tenuicostatum ammonite biozone, and the abundance and diversity of Nannoceratopsis increases upsection (Bucefalo Palliani and Riding, 1997a). Nannoceratopsis magnicornus was described from Quercy, and is also present at Réka Valley (Bucefalo Palliani and Riding, 1997a). The phytoplankton turnover in the higher parts of the lower Toarcian could not be studied at Quercy, because this interval is absent (Bucefalo Palliani and Riding, 1997a).

\subsection{Comparison with the Mediterranean Province}

Mendicodinium spp. are significantly more diverse in the Mediterranean Province than in epicontinental northwest Europe. By contrast, Luehndea and Nannoceratopsis exhibit greater species richness in the latter province (Riding, 1984; Prauss, 1989; Feist-Burkhardt and Wille, 1992). Furthermore, patterns of community and palaeoenvironmental changes associated with the T-OAE also differ between the two areas (Bucefalo Palliani and Riding, 1999b). The only common features are the apparent extinction of Luehndea spinosa before the onset of black shale deposition in the $D$. tenuicostatum ammonite biozone, and the disappearance of dinoflagellate cysts accompanied by a prasinophyte bloom in the organic-rich facies (Bucefalo Palliani et al., 1998; Bucefalo Palliani and Riding, 1999a, 1999b). There is also an apparent discrepancy in the timing of biotic changes and events between the two provinces. In the Umbria-Marche Basin of central Italy, the onset of the environmental perturbation is recorded in the lowermost $D$. tenuicostatum ammonite biozone, culminating in the middle to upper part of that zone, and the return of oxygenated conditions is in the uppermost part of the D. tenuicostatum ammonite biozone (Fig. 9). In Réka Valley, and elsewhere in northwest Europe, the onset of black shale sedimentation and the dinoflagallate cyst disappearance event is higher, i.e. in the uppermost $D$. tenuicostatum to $H$. falciferum ammonite biozones, and the environmental crisis probably extended into the $H$. bifrons ammonite biozone (Prauss et al., 1991). In the Mediterranean region, there is no evidence for elevated terrestrial runoff, freshwater input and the freshening of surface waters, although terrestrial palynomorphs may be sporadically abundant (Bucefalo Palliani, 1997; Bucefalo Palliani and Riding, 1997b). The sphaeromorphs are less significant in the Mediterranean than further north. The palynomorphs in the black shale mainly comprise Tasmanites spp. This prasinophyte proliferation may be due to the expansion of the oxygen minimum zone, and the successful nitrogen metabolism of the prasinophytes (Prauss, 2007). Freshening of the surface waters due to riverine influx was negligible in the Tethyan Realm due to its open oceanic setting (Van de Schootbrugge et al., 2013). After the end of black shale deposition, phytoplankton recovered rapidly, with new taxa including Mancodinium semitabulatum, Mendicodinium spp. and Susadinium, which are not present in coeval strata at Réka Valley (Bucefalo Palliani and Riding, 1999a).

\section{Conclusions}

The palynological and palynofacies analysis of the lower Toarcian black shale-bearing Réka Valley section in southwest Hungary demonstrates significant variations during the T-OAE. The phytoplankton communities responded to the profound environmental stress by exhibiting multiphase change. This has been subdivided into five intervals, with successive reductions in the number of specialist taxa in favour of opportunists. Community replacement was initiated by climate-driven eutrophication and freshening of the surface waters. This lead to maxima (blooms) of the opportunistic dinoflagellate cyst genus Luehndea (Interval 1), and subsequently to an acme of the euryhaline dinoflagellate cyst genus Nannoceratopsis (Interval 2). The most severe environmental crisis was marked by the dominance of prasinophytes, including sphaeromorphs and Tasmanites spp. (Interval 3), indicating reduced nutrient supply and altered physico-chemical conditions of the water column due to water mass stratification. This biotic crisis was followed by a prolonged period of recovery (Intervals 4 and 5).

Comparison of the northwest European and Tethyan Mediterranean provinces in the Toarcian indicates that palaeogeography and regional influences exerted significant control on the composition of phytoplankton communities and turnover patterns. This influenced the dynamics and the extent of the early Toarcian biotic crisis. The five successive stages observed in the Réka Valley succession are consistent with the community replacement pattern documented in epicontinental areas. By contrast, in the Mediterranean Province of the Tethyan Realm, different processes are invoked and there is an apparent temporal discrepancy of biotic events between the two areas. The proliferation of Nannoceratopsis is a regional phenomenon in the northwest European Province. It may represent a response to a regional surface water freshening event which did not affect open oceanic settings; neither is it a global phenomenon. The increase in Nannoceratopsis was triggered by climatic factors, as warming enhanced continental runoff and increased freshwater influx into the epicontinental basins. However the extinction of the Luehndea in the D. tenuicostatum ammonite biozone, and a prasinophyte bloom, is recorded both in northwest Europe and the Mediterranean Luehndea did not survive the low surface salinity and oligotrophic conditions which became established due to the lack of nutrient recirculation in the photic zone. The intensification of oxygen deficiency, oligotrophic conditions and altered availability of trace elements in seawater all caused the prasinophyte bloom. However in epicontinental areas the freshening of surface waters by riverine input cannot be neglected, and this may have led to the proliferation of this 
group. These changes are related to large-scale palaeoclimatic and palaeoenvironmental perturbations that were associated with fundamental changes in the ocean-atmosphere system, oceanic current patterns and the physico-chemical parameters of the seawater.

\section{Acknowledgements}

We thank Maria Barbacka (Hungarian Natural History Museum, Budapest), and András Galácz and István Szente (Eötvös Loránd University, Budapest), for their helpful advice. Emese Réka Bodor (Geological and Geophysical Institute of Hungary, Budapest) is thanked for her assistance in the field, and help with data analysis. Elżbieta Witkowska (Jagiellonian University, Kraków, Poland) and Jadwiga Ziaja (Władysław Szafer Institute of Botany, Kraków, Poland) are acknowledged for their help with taxonomy, and for obtaining literature. Emanuela Mattioli (Université Claude Bernard Lyon 1, France) kindly undertook calcareous nannofossil analyses during an earlier project on the section studied. We thank Wolfram M. Kürschner (University of Oslo, Norway) for his constructive comments on an early draft of the manuscript. Two anonymous reviewers provided constructive comments and help in improving this article. The research was financed by the Hungarian Scientific Research Fund (project K72633) and the Hantken Miksa Foundation. Viktória Baranyi was also supported by an AASP Student Scholarship in 2013. James B. Riding publishes with the approval of the Executive Director, British Geological Survey (NERC). This is MTM-MTA-ELTE Palaeo contribution number 226.

\section{Appendix A. List of palynomorph species}

This Appendix lists all valid palynomorph taxa below generic level from the Réka Valley section, or mentioned herein, with full author citations. The palynomorphs are listed alphabetically within five groups. References to the dinoflagellate cyst author citations can be found in Fensome and Williams (2004).

\section{Acritarch:}

Micrhystridium lymensis Wall 1965

Dinoflagellate cysts:

Luehndea cirilliae Bucefalo Palliani et al. 1997

Luehndea microreticulata Bucefalo Palliani et al. 1997

Luehndea spinosa Morgenroth 1970

Mancodinium semitabulatum Morgenroth 1970

Maturodinium inornatum Morgenroth 1970

Nannoceratopsis gracilis Alberti 1961

Nannoceratopsis gracilis Alberti 1961 subsp. obsoleta (Prauss 1989)

Lentin \& Williams 1993

Nannoceratopsis magnicornus Bucefalo Palliani \& Riding 1998

Nannoceratopsis senex van Helden 1977

Nannoceratopsis spiculata Stover 1966

Umbriadinium mediterraneense Bucefalo Palliani \& Riding 1997

Valveodinium armatum Morgenroth 1970

Pollen:

Alisporites robustus Nilsson 1958

Alisporites sp. cf. A. thomasii (Couper 1958) Nilsson 1958

Chasmatosporites elegans Nilsson 1958

Monosulcites minimus Cookson 1947

Monosulcites subgranulosus Couper 1958

Spheripollenites psilatus Couper 1958

Vitreisporites pallidus (Reissinger 1950) Nilsson 1958

Prasinophytes:

Cymatiosphaera pachytheca Eisenack 1967

Halosphaeropsis liassica Mädler 1963

Pleurozonaria polyporosa Mädler 1963

Spores:

Auritulinasporites triclavis Nilsson 1958

Cibotiumspora jurienensis (Balme 1957) Filatoff 1965

Conbaculatisporites mesozoicus Klaus 1960
Concavisporites toralis (Leschik 1955) Nilsson 1958 Contignisporites problematicus (Couper 1958) Döring 1965

Cyathidites australis Couper 1953

Cyathidites minor Couper 1953 1963

Cyathidites punctatus (Delcourt \& Sprumont 1955) Delcourt et al.

Dictyophyllidites harrisii Couper 1958

Ischyosporites variegatus Couper 1958

Leptolepidites verrucatus Couper 1953

Manumia delcourtii (Pocock 1970) Dybkjær 1991

Osmundacidites wellmanii Couper 1953

Plicifera delicata (Bolkhovitina 1953) Bolkhovitina 1966

Uvaesporites argenteaeformis (Bolkhovitina 1953) Schulz 1967

\section{Appendix B. Supplementary data}

Supplementary data to this article can be found online at http://dx. doi.org/10.1016/j.revpalbo.2016.09.011.

\section{References}

Abbink, O.A., Van Konijnenburg-Van Cittert, J.H.A., Visscher, H., 2004. A sporomorph ecogroup model for the Northwest European Jurassic-Lower Cretaceous. Concepts and framework. Neth. J. Geosci. 83, 17-38.

Adámek, J., 2005. The Jurassic floor of the Bohemian Massif in Moravia - geology and paleogeography. Bull. Geosci. 80, 291-305.

Anderson, D.M., Taylor, C.D., Armbrust, E.V., 1987. The effects of darkness and anaerobiosis on dinoflagellate cyst germination. Limnol. Oceanogr. 32, 340-351.

Bailey, T.R., Rosenthal, Y., McArthur, J.M., van de Schootbrugge, B., Thirlwall, M.F., 2003. Paleoceanographic changes of the Late Pliensbachian-Early Toarcian interval: a possible link to the genesis of an Oceanic Anoxic Event. Earth Planet. Sci. Lett. 212, 307-320.

Baldanza, A., Bucefalo Palliani, R., Mattioli, E., 1995. Lower Jurassic calcareous nannofossils and dinoflagellate cysts of Hungary and their comparison with assemblages from Central Italy. Palaeopelagos 5, 161-174.

Bassoulet, J.-P., Elmi, S., Poisson, A., Cecca, F., Bellion, Y., Guiraud, R., Baudin, F., 1993. Middle Toarcian (184-182 Ma.). In: Dercourt, J., Ricou, L.E., Vrielynck, B. (Eds.), Atlas Tethys Paleoenvironmental Maps. BEICIP-FRANLAB, Rueil-Malmaison, pp. 63-80.

Batten, D.J., 2002. Palynofacies and petroleum potential. In: Jansonius, J., McGregor, D.C. (Eds.), Palynology: Principles and Applications 3. American Association of Stratigraphic Palynologists Foundation, pp. 1065-1084.

Bleahu, M., Mantea, G., Bordea, S., Panin, S., Stefãnescu, M., Sikić, K., Haas, J., Kovács, S. Péró, C., Bérczi-Makk, A., Konrád, G., Nagy, E., Rálisch-Felgenhauer, E., Török, Á., 1994. Triassic facies types, evolution and paleogeographic relations of the Tisza Megaunit. Acta Geol. Hung. 37, 187-234.

Bonis, N.R., Kürschner, W.M., Krystyn, L., 2009. A detailed palynological study of the Triassic-Jurassic transition in key sections of the Eiberg Basin (Northern Calcareous Alps, Austria). Rev. Palaeobot. Palynol. 156, 376-400.

Branski, P., 2010. Kaolinite peaks in early Toarcian profiles from the Polish Basin - an inferred record of global warming. Geol. Q. 54, 15-24.

Bucefalo Palliani, R., 1997. Toarcian sporomorph assemblages from the Umbria-Marche basin, central Italy. Palynology 21, 105-121.

Bucefalo Palliani, R., Riding, J.B., 1997a. The influence of palaeoenvironmental change on dinoflagellate cyst distribution. An example from the Lower and Middle Jurassic of Quercy, southwest France. Bull. Cent. Rech. Elf Explor. Prod. 21, 107-123.

Bucefalo Palliani, R., Riding, J.B., 1997b. Lower Toarcian palynostratigraphy of Pozzale, central Italy. Palynology 21, 91-103.

Bucefalo Palliani, R., Riding, J.B., 1999a. Relationship between the early Toarcian anoxic event and organic-walled phytoplankton in central Italy. Mar. Micropaleontol. 37. 101-116.

Bucefalo Palliani, R., Riding, J.B., 1999b. Early Jurassic (Pliensbachian-Toarcian) dinoflagellate migrations and cyst paleoecology in the Boreal and Tethyan realms. Micropaleontology 45, 201-214.

Bucefalo Palliani, R., Riding, J.B., 2000. A palynological investigation of the Lower and lowermost Middle Jurassic strata (Sinemurian to Aalenian) from North Yorkshire, UK. Proc. Yorks. Geol. Soc. 53, 1-16.

Bucefalo Palliani, R., Riding, J.B., 2003a. Biostratigraphy, provincialism and evolution of European Early Jurassic (Pliensbachian to early Toarcian) dinoflagellate cysts. Palynology 27, 179-214.

Bucefalo Palliani, R., Riding, J.B., 2003b. Umbriadinium and Polarella: an example of selectivity in the dinoflagellate fossil record. Grana 42, 108-111.

Bucefalo Palliani, R., Riding, J.B., Torricelli, S., 1997. The dinoflagellate cyst Luehndea Morgenroth, 1970, emend. From the upper Pliensbachian (Lower Jurassic) of Hungary. Rev. Palaeobot. Palynol. 96, 113-120.

Bucefalo Palliani, R., Cirilli, S., Mattioli, E., 1998. Phytoplankton response and geochemical evidence of the lower Toarcian relative sea level rise in the Umbria Marche basin (Central Italy). Palaeogeogr. Palaeoclimatol. Palaeoecol. 142, 33-50.

Bucefalo Palliani, R., Mattioli, E., Riding, J.B., 2002. The response of marine phytoplankton and sedimentary organic matter to the early Toarcian (Lower Jurassic) oceanic anoxic event in northern England. Mar. Micropaleontol. 46, 223-245. 
Burgess, S.D., Bowring, S.A., Fleming, T.H., Elliot, D.H., 2015. High-precision geochronology links the Ferrar large igneous province with early-Jurassic ocean anoxia and biotic crisis. Earth Planet. Sci. Lett. 415, 90-99.

Caruthers, A.H., Smith, P., Gröcke, D.R., 2013. The Pliensbachian-Toarcian (Early Jurassic) extinction, a global multi-phased event. Palaeogeogr. Palaeoclimatol. Palaeoecol. 386, 104-118.

Caswell, B.A., Coe, A.L., 2013. Primary productivity controls on opportunistic bivalves during Early Jurassic oceanic deoxygenation. Geology 41, 1163-1166.

Correa-Metrio, A., Dechnik, Y., Socorro, L.-G., Caballero, M., 2014. Detrended correspondence analysis: a useful tool to quantify ecological changes from fossil data sets. Bol. Soc. Geol. Mex. 66, 135-143.

Császár, G., Görög, Á., Gyuricza, G., Sieglné Farkas, Á., Szente, I., Szinger, B., 2007. The geological, palaeontological and sedimentological pattern of the Vasa Marl Formation between Zsibrik and Ófalu, South Transdanubia. Földtani Közlöny 137, $193-226$.

Csontos, L., Vörös, A., 2004. Mesozoic plate tectonic reconstruction of the Carpathian region. Palaeogeogr. Palaeoclimatol. Palaeoecol. 210, 1-56.

Csontos, L., Nagymarosy, A., Horváth, F., Kovác, M., 1992. Tertiary evolution of the IntraCarpathian area: a model. Tectonophysics 208, 221-241.

Csontos, L., Benkovics, L., Bergerat, F., Mansy, J., Wórum, G., 2002. Tertiary deformation history from seismic section study and fault analysis in a former European Tethyan margin (the Mecsek-Villány area, SW Hungary). Tectonophysics 357, 81-102.

Danise, S., Twitchett, R.J., Little, T.S., Clémance, M.-E., 2013. The impact of global warming and anoxia on marine benthic community dynamics: an example from the Toarcian (Early Jurassic). PLoS One 8, e56255.

Davies, E.H., 1985. The miospore and dinoflagellate cyst Oppel-zonation of the Lias of Portugal. Palynology 9, 105-132.

De Toledo, M.B., Barth, O.M., Silva, C.G., Barros, M.A., 2009. Testing multivariate analysis in paleoenvironmental reconstructions using pollen records from Lagoa Salgada, NE Rio de Janeiro State, Brazil. Ann. Braz. Acad. Sci. 81, 757-768.

Dera, G., Pellenard, P., Neige, P., Deconinck, J.-F., Pucéat, E., Dommergues, J.-L., 2009. Distribution of clay minerals in Early Jurassic Peritethyan seas: palaeoclimatic significance inferred from multiproxy comparisons. Palaeogeogr. Palaeoclimatol. Palaeoecol. 271, 39-51.

Diaz, R.J., Rosenberg, R., 2008. Spreading dead zones and consequences for marine ecosystems. Science 321, 926-929.

Dulai, A., Suba, Z., Szarka, A., 1992. Toarcian (Lower Jurassic) organic-rich black shale in the Réka valley (Mecsek Hills, Hungary). Földtani Közlöny 122, 67-87.

Dybkjær, K., 1991. Palynological zonation and palynofacies investigation of the Fjerritslev Formation (Lower Jurassic-basal Middle Jurassic) in the Danish Subbasin. Dan. Geol. Unders. Ser. A 30 (150 pp.).

Ellegaard, M., 2000. Variations in dinoflagellate cyst morphology under conditions of changing salinity during the last 2000 years in the Limfjord, Denmark. Rev. Palaeobot. Palynol. 109, 65-81.

Erba, E., 2004. Calcareous nannofossils and Mesozoic oceanic anoxic events. Mar. Micropaleontol. 52, 85-106.

Evitt, W.R., 1961. The dinoflagellate Nannoceratopsis Deflandre; morphology, affinities and infraspecific variability. Micropaleontology 7, 305-316.

Falkowski, P.G., Katz, M.E., Knoll, A.H., Quigg, A., Raven, J.A., Schofield, O., Taylor, F.J.R., 2004. The evolution of modern eukaryotic phytoplankton. Science 305 , 354-360.

Farrimond, P., Eglinton, G., Brassell, S.C., Jenkyns, H.C., 1989. Toarcian anoxic event in Europe: an organic geochemical study. Mar. Pet. Geol. 6, 136-147.

Feist-Burkhardt, S., Wille, W., 1992. Jurassic palynology in southwest Germany - state of the art. Cah. Micropaleontol. 7, 141-164.

Feist-Burkhardt, S., Götz, A., Ruckwied, K., Russel, J., 2008. Palynofacies patterns, acritarch diversity and stable isotope signatures in the Lower Muschelkalk (Middle Triassic) of N Switzerland: evidence of third-order cyclicity. Swiss J. Geosci. 101, 1-15.

Fensome, R.A., Williams, G.L., 2004. The Lentin and Williams index of fossil dinoflagellates. American Association of Stratigraphic Palynologists Contributions Series No. 42, 2004 edition (909 pp.).

Fensome, R.A., Taylor, F.J.R., Norris, G., Sarjeant, W.A.S., Wharton, D.I., Williams, G.L., 1993. A classification of living and fossil dinoflagellates. Micropaleontology Press Special Paper 7 (351 pp.)

Galácz, A., 1991. Palaeontological investigation of the Toarcian black shale in the Mecsek Mts. Department of Palaeontology, Eötvös Loránd University, unpublished manuscript (32 pp.).

Gocht, H., 1964. Planktonische Kleinformen aus dem Lias-/Dogger-Grenzbereich Nordund Süddeutschlands. Neues Jb. Geol. Paläontol. Abh. 119, 113-133.

Gocht, H., 1972. Zur Morphologie der Dinoflagellaten-Gattung Nannoceratopsis Deflandre. Lethaia 5, 15-29.

Götz, A.E., Feist-Burkhardt, S., Ruckwied, K., 2008. Palynofacies and sea-level changes in the Upper Cretaceous of the Vocontian Basin, southeast France. Cretac. Res. 29, 1047-1057.

Grimm, E.C., 1987. CONISS: a FORTRAN 77 program for stratigraphically constrained cluster analysis by the method of incremental sum of squares. Comput. Geosci. $13,13-35$

Grimm, E.C., 1991-2001. Tilia, TiliaGraph and TGView Software. Illinois State Museum, Springfield, Illinois, USA.

Guy-Ohlson, D., 1986. Jurassic palynology of the Vilhelmsfält Bore No. 1, Scania, Sweden Toarcian-Aalenian. Swedish Museum of Natural History, Stockholm (127 pp.).

Haas, J., Péró, C., 2004. Mesozoic evolution of the Tisza Mega-unit. Int. J. Earth Sci. 93, 297-313.

Hammer, Ø., Harper, D.A.T., Ryan, P.D., 2001. PAST: palaeontological statistics software package for education and data analysis. Palaeontol. Electron. 4, 9 .
Harries, P.J., Little, C.T.S., 1999. The early Toarcian (Early Jurassic) and the CenomanianTuronian (Late Cretaceous) mass extinctions: similarities and contrasts. Palaeogeogr. Palaeoclimatol. Palaeoecol. 154, 39-66.

Hermoso, M., Minoletti, F., Pellenard, P., 2013. Black shale deposition during Toarcian super-greenhouse driven by sea level. Clim. Past 9, 2703-2712.

Hesselbo, S.P., Gröcke, D.R., Jenkyns, H.C., Bjerrum, C.J., Farrimond, P., Green, O.R., 2000. Massive dissociation of gas hydrate during a Jurassic oceanic anoxic event. Nature 406, 392-395.

Hesselbo, S.P., Jenkyns, H.C., Duarte, L.V., Oliveira, L.C.V., 2007. Carbon-isotope record of the Early Jurassic (Toarcian) Oceanic Anoxic Event from fossil wood and marine carbonate (Lusitanian Basin, Portugal). Earth Planet. Sci. Lett. 253, 455-470.

Hill, M.O., Gauch, H.G., 1980. Detrended correspondence analysis: an improved ordination technique. Vegetatio 42, 47-58.

Horváth, F., Galácz, A., 2006. The Carpathian-Pannonian Region. A review of Mesozoic-Cenozoic stratigraphy and tectonics. Hantken Press, Budapest (624 pp.).

Jenkyns, H.C., 1988. The early Toarcian (Jurassic) anoxic event; stratigraphic, sedimentary and geochemical evidence. Am. J. Sci. 288, 101-151.

Jenkyns, H.C., Gröcke, D.R., Hesselbo, S.P., 2001. Nitrogen isotope evidence for water mass denitrification during the early Toarcian (Jurassic) oceanic anoxic event. Paleoceanography 16, 1-11.

Jenkyns, H.C., Jones, C.E., Gröcke, D.R., Hesselbo, S.P., Parkinson, D.N., 2002. Chemostratigraphy of the Jurassic System: applications, limitations and implications for palaeoceanography. J. Geol. Soc. 159, 351-378.

Katz, M.E., Finkel, Z.V., Grzebyk, D., Knoll, A.H., Falkowski, P.G., 2004. Evolutionary trajectories and biochemical impacts of marine eukaryotic phytoplankton. Annu. Rev. Ecol. Evol. Syst. 35, 523-556.

Korte, C., Hesselbo, S.P., 2011. Shallow marine carbon and oxygen isotope and elemental records indicate icehouse-greenhouse cycles during the Early Jurassic. Paleoceanography 26, PA4219.

Kovach, W.L., 1993. Multivariate techniques for biostratigraphical correlation. J. Geol. Soc. $150,697-705$.

Legendre, P., Legendre, L., 1998. Numerical Ecology. Elsevier Scientific, Oxford.

Littler, K., Hesselbo, S.P., Jenkyns, H.C., 2009. A carbon-isotope perturbation at the Pliensbachian-Toarcian boundary: evidence from the Lias Group, NE England. Geol. Mag. 147, 181-192.

Loh, H., Maul, B., Prauss, M., Riegel, W., 1986. Primary production, maceral formation and carbonate species in the Posidonia Shale of NW Germany. Mitt. Geol.-Palaontol. Inst. Univ. Hamburg 60, 397-421.

Lund, J.J., Pedersen, K.R., 1984. Palynology of the marine Jurassic formations in the Vardekløft ravine, Jameson Land, East Greenland. Bull. Geol. Soc. Den. 33, 371-400.

Marret, F., Zonneveld, K., 2003. Atlas of modern organic-walled dinoflagellate cyst distribution. Rev. Palaeobot. Palynol. 125, 1-200.

Mattioli, E., Erba, E., 1999. Synthesis of calcareous nannofossil events in Tethyan Lower and Middle Jurassic succesions. Riv. Ital. Paleontol. Stratigr. 105, 343-376.

Mattioli, E., Pittet, B., Bucefalo Palliani, R., Röhl, H.-J., Schmid-Röhl, A., Morettini, E., 2004. Phytoplankton evidence for the timing and correlation of palaeoceanographical changes during the early Toarcian oceanic anoxic event (Early Jurassic). J. Geol. Soc. 164, 685-693.

Mattioli, E., Pittet, B., Petitpierre, L., Maillot, S., 2009. Dramatic decrease of pelagic carbonate production by nannoplankton across the Early Toarcian anoxic event (T-OAE). Glob. Planet. Chang. 65, 134-145.

McArthur, J.M., Donovan, D.T., Thirlwall, M.F., Fouke, B.W., Mattey, D., 2000. Strontium isotope profile of the early Toarcian (Jurassic) oceanic anoxic event, the duration of ammonite biozones, and belemnite palaeotemperatures. Earth Planet. Sci. Lett. 179, 269-285.

McDonald, J.H., 2014. Handbook of Biological Statistics. 3rd edition. Sparky House Publishing, Baltimore (305 pp.)

McElwain, J.C., Wade-Murphy, J., Hesselbo, S.P., 2005. Changes in carbon dioxide during an oceanic anoxic event linked to intrusion into Gondwana coals. Nature 435, 479-482.

Mertens, K.N., Bradley, L.R., Takano, Y., Mudie, P.J., Marret, F., Aksu, A.E., Hiscott, R.N., Verleye, T.J., Mousing, E.A., Smyrnova, L., Bagheri, S., Mansor, M., Pospelova, V., Matsuoka, K., 2012. Quantitative estimation of Holocene surface salinity variation in the Black Sea using dinoflagellate cyst process length. Quat. Sci. Rev. 39, 45-59.

Némedi Varga, Z., 1998. Jurassic lithostratigraphy of the Mecsek and Villany. In: Bérczi, I., Jámbor, Á. (Eds.), Lithostratigraphic Units in Hungary. Geological Institute of Hungary, Budapest, pp. 319-336.

Oboh-Ikuenobe, F.E., de Villiers, S.E., 2003. Dispersed organic matter in samples from the western continental shelf of Southern Africa: palynofacies assemblages and depositional environments of Late Cretaceous and younger sediments. Palaeogeogr. Palaeoclimatol. Palaeoecol. 201, 67-88.

Pálfy, J., Smith, P.L., 2000. Synchrony between Early Jurassic extinction, oceanic anoxic event, and the Karoo-Ferrar flood basalt volcanism. Geology 28, 747-750.

Pittet, B., Gorin, G.E., 1997. Distribution of sedimentary organic matter in a mixed carbonate-siliciclastic platform environment: Oxfordian of the Jura Mountains. Sedimentology 44, 915-937.

Poulsen, N.E., 1992. Jurassic dinoflagellate cyst biostratigraphy of the Danish Subbasin in relation to sequences in England and Poland; a preliminary review. Rev. Palaeobot. Palynol. 75, 33-52.

Poulsen, N.E., Riding, J.B., 2003. The Jurassic dinoflagellate cyst zonation of Subboreal Northwest Europe. Geol. Surv. Den. Greenl. Bull. 1, 115-144.

Prauss, M., 1989. Dinozysten-Stratigraphie und Palynofazies im Oberen Lias und Dogger von NW-Deutschland. Palaeontogr. Abt. B 214, 1-124.

Prauss, M., 1996. The Lower Toarcian Posidonia Shale of Grimmen, Northeast Germany. Implications from the palynological analysis of a near-shore section. Neues Jb. Geol. Paläontol. Abh. 200, 107-132. 
Prauss, M., 2007. Availability of reduced nitrogene chemospecies in photic-zone waters as the ultimate cause for fossil prasinophyte prosperity. Palaios 22, 489-499.

Prauss, M., Riegel, W., 1989. Evidence from phytoplankton associations for causes of black shale formation in epicontinental seas. Neues Jb. Geol. Paläontol. Monat. 11, 671-682.

Prauss, M., Ligouis, B., Luterbacher, H.-P., 1991. Organic matter and palynomorphs in the "Posidonienschiefer" (Toarcian, Lower Jurassic) of southern Germany. In: Tyson, R.V., Pearson, T.H. (Eds.), Modern and Ancient Continental Shelf Anoxia. Geological Society of London Special Publication 58, pp. 335-351.

Pross, J., 2001. Paleo-oxygenation in Tertiary epeiric seas: evidence from dinoflagellate cysts. Palaeogeogr. Palaeoclimatol. Palaeoecol. 166, 369-381.

Raucsik, B., 2008. Apátvarasd, Réka Valley, opposite to the Disznós Spring, black shale outcrop. In: Galácz, A., Konrád, G., Vörös, A. (Eds.), Jurassic Siliciclastics and Carbonates of the Mecsek-Villány Area. Field Trip Guide of the Geological Excursion on the Mecsek and Villány Hills. Hungarian Geological Society and the Sedimentological Subcommission of the Hungarian Academy of Sciences, pp. 33-37.

Raucsik, B., 2012a. Vasas Marl Formation. In: Főzy, I. (Ed.), Jurassic Lithostratigraphic Units in Hungary. Hungarian Geological Society, pp. 152-154.

Raucsik, B., 2012b. Hosszúhetény Calcareous Marl Formation. In: Főzy, I. (Ed.), Jurassic Lithostratigraphic Units in Hungary. Hungarian Geological Society, pp. 155-158.

Raucsik, B., 2012c. Rékavölgy Siltstone Formation. In: Főzy, I. (Ed.), Jurassic Lithostratigraphic Units in Hungary. Hungarian Geological Society, pp. 164-167.

Raucsik, B., 2012d. Komló Calcareous Marl Formation. In: Főzy, I. (Ed.), Jurassic Lithostratigraphic Units in Hungary. Hungarian Geological Society, pp. 174-176.

Raucsik, B., Varga, A., 2008a. Climato-environmental controls on clay mineralogy of the Hettangian-Bajocian successions of the Mecsek Mountains, Hungary: evidence for extreme continental weathering during the early Toarcian oceanic anoxic event. Palaeogeogr. Palaeoclimatol. Palaeoecol. 265, 1-13.

Raucsik, B., Varga, A., 2008b. Mineralogy of the Lower Toarcian black shale section from the Réka Valley (Óbánya Siltstone Formation, Mecsek Mountains, Hungary): implications for palaeoclimate. Földtani Közlöny 138, 133-146.

Riding, J.B., 1983. The palynology of the Aalenian (Middle Jurassic) sediments of Jackdaw Quarry, Gloucestershire, England. Mercian Geol. 9, 111-120.

Riding, J.B., 1984. A palynological investigation of Toarcian to early Aalenian strata from the Blea Wyke area, Ravenscar, North Yorkshire. Proc. Yorks. Geol. Soc. 45, 109-122.

Riding, J.B., 1987. Dinoflagellate cyst stratigraphy of the Nettleton Bottom Borehole (Jurassic: Hettangian to Kimmeridgian) Lincolnshire, England. Proc. Yorks. Geol. Soc. 46, 231-266.

Riding, J.B., Thomas, J.E., 1992. Dinoflagellate cysts of the Jurassic System. In: Powell, A.J. (Ed.), A Stratigraphic Index of Dinoflagellate Cysts. British Micropalaeontological Society Publications Series, pp. 7-97.

Riding, J.B., Penn, I.E., Woollam, R., 1985. Dinoflagellate cysts from the type area of the Bathonian Stage (Middle Jurassic; south-west England). Rev. Palaeobot. Palynol. 45, 149-170.

Rochon, A., Lewis, J., Ellegaard, M., Harding, I.C., 2009. The Gonyaulax spinifera (Dinophyceae) "complex": perpetuating the paradox? Rev. Palaeobot. Palynol. 155, 52-60.

Röhl, H.-J., Schmid-Röhl, A., 2005. Lower Toarcian (Upper Liassic) black shales of the Central European epicontinental basin: a sequence stratigraphic case study from the SW Germany, Posidonia Shale. SEPM Spec. Publ. 82, 165-189.

Schouten, S., van Kaam-Peters, H.M.E., Rijpstra, W.I.C., Schoell, M., Sinnighe Damaste, J.S., 2000. Effects of an anoxic event on the stable carbon isotope composition of Early Toarcian carbon. Am. J. Sci. 300, 1-22.

Stover, L.E., Brinkhuis, H., Damassa, S.P., de Verteuil, L., Helby, R.J., Monteil, E., Partridge, A.D., Powell, A.J., Riding, J.B., Smelror, M., Williams, G.L., 1996. Mesozoic-Tertiary dinoflagellates, acritarchs and prasinophytes. In: Jansonius, J., McGregor, D.C. (Eds.), Palynology: Principles and Applications 2. American Association of Stratigraphic Palynologists Foundation, pp. 641-750.
Suan, G., Mattioli, E., Pittet, B., Maillot, S., Lécuyer, C., 2008. Evidence for major environmental perturbation prior to and during the Toarcian (Early Jurassic) oceanic anoxic event from the Lusitanian Basin, Portugal. Paleoceanography 23, PA1202.

Svensen, H., Planke, S., Chevallier, L., Malthe-Sørenssen, A., Corfu, F., Jamtveit, B., 2007. Hydrothermal venting of greenhouse gases triggering Early Jurassic global warming. Earth Planet. Sci. Lett. 256, 554-566.

Szente, I., 2012. Mecsek Coal Formation. In: Főzy, I. (Ed.), Jurassic Lithostratigraphic Units in Hungary. Hungarian Geological Society, pp. 145-148.

Taylor, F.J.R., Hoppenrath, M., Saldarriaga, J.F., 2008. Dinoflagellate diversity and distribution. Biodivers. Conserv. 17, 407-418.

Tyson, R.V., 1993. Palynofacies analysis. In: Jenkins, D.G. (Ed.), Applied Micropaleontology. Kluwer Academic Publishers, The Netherlands, pp. 153-191.

Tyson, R.V., 1995. Sedimentary organic matter: organic facies and palynofacies. Chapman and Hall, London (615 pp.).

Van de Schootbrugge, B., McArthur, J.M., Bailey, T.R., Rosenthal, Y., Wright, J.D., Miller, K.G., 2005a. Toarcian oceanic anoxic event: assessment of global causes using belemnite C-isotope records. Paleoceanography 20, PA3008.

Van de Schootbrugge, B., Bailey, T.R., Rosenthal, Y., Katz, M.E., Wright, J.D., Miller, K.G., Feist-Burkhardt, S., Falkowski, P.G., 2005b. Early Jurassic climate change and the radiation of organic-walled phytoplankton in the Tethys Ocean. Paleobiology 31, 73-97.

Van de Schootbrugge, B., Quan, T.M., Lindström, S., Püttmann, W., Heunisch, C., Pross, J., Fiebig, J., Petschick, R., Röhling, H., Richoz, H.-G., Rosenthal, Y., Falkowski, P.G., 2009. Floral changes across the Triassic-Jurassic boundary linked to flood basalt volcanism. Nat. Geosci. 2, 589-594.

Van de Schootbrugge, B., Bachan, A., Suan, G., Richoz, S., Payne, J.L., 2013. Microbes, mud and methane: cause and consequence of recurrent Early Jurassic anoxia following the end-Triassic mass extinction. Palaeontology 56, 685-709.

Van Erve, A.W., 1977. Palynological investigation in the Lower Jurassic of the Vicentinian Alps (Northeastern Italy). Rev. Palaeobot. Palynol. 23, 1-117.

Varga, A.R., Raucsik, B., Hámor-Vidó, M., Rostási, A., 2007. Isotope geochemistry and characterization of hydrocarbon potential of black shale from Óbánya Siltstone Formation. Földtani Közlöny 137, 449-472.

Varga, A., Mikes, T., Raucsik, B., 2009. The petrography and heavy minerals of the Toarcian black shale of the Réka Valley section of the Mecsek Hills: a pilot study. Földtani Közlöny 139, 31-53.

Verleye, T.J., Mertens, K.N., Young, M.D., Dale, B., McMinn, A., Scott, L., Zonneveld, K.A.F. Louwye, S., 2012. Average process length variation of the marine dinoflagellate cyst Operculodinium centrocarpum in the tropical and Southern Hemisphere oceans: assessing its potential as a palaeosalinity proxy. Mar. Micropaleontol. 86-87, 45-58.

Wall, D., 1965. Microplankton, pollen, and spores from the Lower Jurassic in Britain. Micropaleontology 11, 151-190.

Wall, D., Dale, B., Lohmann, G.P., Smith, W.K., 1977. The environmental and climatic distribution of dinoflagellate cysts in modern marine sediments from regions in the North and south Atlantic oceans and adjacent seas. Mar. Micropaleontol. 2, 121-200.

Wignall, P.B., 2001. Large igneous provinces and mass extinctions. Earth Sci. Rev. 53, 1-33.

Wignall, P.B., Benton, M.J., 1999. Lazarus taxa and fossil abundances at times of biotic crisis. J. Geol. Soc. Lond. 156, 453-456.

Wille, W., 1982. Ecology and evolution of Upper Liassic dinoflagellates from SW Germany Neues Jb. Geol. Paläontol. Abh. 164, 74-82.

Wood, G.D., Gabriel, A.M., Lawson, J.C. 1996. Palynological techniques - processing and microscopy. In: Jansonius, J., McGregor, D.C. (Eds.), Palynology: Principles and Applications 1. American Association of Stratigraphic Palynologists Foundation, pp. 29-50.

Woollam, R., Riding, J.B., 1983. Dinoflagellate cyst zonation of the English Jurassic. Inst. Geol. Sci. Rep. 83 (2), 1-44. 